\title{
A review of the mitigation of deposition and emission problems during biomass combustion through washing pre-treatment.
}

\author{
Bijal Gudka ${ }^{\mathrm{a}}$, Jenny M. Jones ${ }^{\mathrm{a}}$, Amanda R. Lea-Langton ${ }^{\mathrm{a}}$, Alan Williams ${ }^{\mathrm{a}}$, Abby Saddawi ${ }^{\mathrm{b}}$ \\ ${ }^{a}$ Energy Research Institute, School of Chemical and Process Engineering, University of \\ Leeds, Leeds, LS2 9JT, UK \\ ${ }^{\mathrm{b}}$ School of Engineering, University of Lincoln, Lincoln, Lincolnshire, LN6 7TS, UK
}

\begin{abstract}
Pre-treatment of biomass via washing has shown to reduce the ash deposition and air-borne emissions. Particle size and temperature are important parameters to consider when washing biomass. Washing removes the problematic chemical species like $\mathrm{K} \mathrm{Na}, \mathrm{Ca}, \mathrm{Mg}, \mathrm{Fe}, \mathrm{Cl}, \mathrm{S}$ and $\mathrm{P}$ from the biomass. Hot water washing improves the removal efficiency of these metals, therefore increasing the ash melting temperatures. Removal of $\mathrm{S}$ and $\mathrm{Cl}$ reduce acid gases formation and hence corrosion in boilers and associated environmental impact.
\end{abstract}

Keywords: biomass, ash, air-borne emissions, washing, temperature, ash-melting.

Highlights:

There is significant reduction in ash content after washing.

Problematic elements during combustion such as; $\mathrm{K}, \mathrm{Cl}$ and $\mathrm{S}$ are removed

Hot water washing accelerates the removal of chemical species from biomass.

Washing can be a positive solution to utilising waste wood for power generation.

\section{Introduction}

Biomass, especially in the form of white wood pellets, has become an internationally traded fuel for the growing needs of the bioenergy industry. In many of the industrialised countries, the UK included, bioenergy has become embedded in Government strategies for reducing greenhouse gas emissions from electricity, heat and transportation [1]. A major and growing market is white wood pellets for electricity generation, particularly for co-firing with coal in large coal boilers, or for situations such as complete conversion of coal units to biomass. White wood pellets are desirable for a number of reasons: pelletisation improves the volumetric energy content of the biomass and lowers the cost and carbon emissions associated with transportation and handling; regularly shaped pellets can be handled more easily than chip; energy requirements are lower for milling pellets to small particle size for pulverised fuel boilers; white wood pellets have standardised specifications [2] and so can meet the stringent requirements of the utility companies to minimise issues of deposition and corrosion. The main elements of concern are chlorine, sulphur, and alkali metals, as well as nitrogen, because of its impact on $\mathrm{NO}_{\mathrm{x}}$ emissions. Pellets for non-industrial use (i.e. fuel for 
smaller appliances for domestic, small commercial and public sector building installation) are covered by EN 14961-2 [3] This is sub-divided into three main classes: Class A1- covers pellets manufactured from virgin timber and chemically untreated wood residues and is low in ash, nitrogen and chlorine. It consists of virgin sawdust from the stem wood (bark removed) or untreated timber. Class A2 is similar to A1 but with slightly higher ash, nitrogen and chlorine levels and largely consists of tree chippings, including bark. Class B covers pellets containing some proportion of chemically treated and used wood with heavy metal content below specified threshold levels and uses recycled wood. Class $\mathrm{C}$ is not suitable for these applications and is contaminated by paint or preservative. It must be burned in industrial plant.

Whilst the supply of wood chips is on an internationally traded basis the recycled wood is more on a local supply basis. The quantities available are quite considerable and in the UK is about one Mty $^{-1}$ of waste wood which is suitable as a fuel. Previously most of the pretreatment of biomass via washing has been done for agricultural residues but further studies are now being conducted on woody biomass. In order to tackle the deposition and corrosion problems, biomass is pre-treated using various technologies to improve its properties. This paper reviews the pre-treatment of biomass via washing.

\section{Biomass Properties}

\subsection{Biomass Composition}

Tables 1 summarises some typical ranges of compositions for different types of biomass. It is clear that there can be wide variation, and this depends not only on the type of biomass, but also on other factors such as, the geographical location and soil type, the age of the wood and the amount of wood and bark in woody biomass. In the case of agricultural residues from some industrial processes; the amount of shells, husks and pits and the way in which the crops are processed also influence their composition [4]. Work on energy crop agronomy has shown that inorganics can also vary with fertilizer treatment and time of harvest, as well as the part of the biomass (leaf, stem etc) [5-10].

\subsection{Ash composition and deposition problems during combustion}

Typical ash compositions are given in Tables 2-4 for different biomass. In Tables 2 to 4, the slagging and fouling indices have been calculated by the authors of this paper. The major elements are the essential minerals for plant growth and include $\mathrm{Si}, \mathrm{Ca}, \mathrm{K}, \mathrm{Al}, \mathrm{Fe}, \mathrm{Mg}, \mathrm{Ti}$, $\mathrm{Na}, \mathrm{P}$ and $\mathrm{S}$. Essential minor minerals make up the trace elements of the biomass, although some also arise through contamination. Waste wood can pose unique problems because of potential contamination from paint, plastic and preservatives (the latter affecting the copper chromium and arsenic concentrations (CCA)). Table 5 indicates typical levels of trace metals in a selection of biomass. 
Table 1 Ultimate analysis of various biomass and solid waste fuels [11]

\begin{tabular}{|c|c|c|c|c|c|c|c|c|c|c|c|}
\hline \multicolumn{8}{|c|}{ Ultimate analysis $(\mathrm{db})$} & \multicolumn{4}{|c|}{ Proximate analysis (a.r. or db) } \\
\hline Fuel Sample & $\mathrm{C}$ & $\mathrm{H}$ & $\mathrm{N}$ & $\mathrm{S}$ & $\mathrm{Cl}$ & $\mathrm{O}$ & HHV & Moisture & Ash & Volatile matter & Fixed carbon \\
\hline \multicolumn{12}{|l|}{ Woody } \\
\hline Eucalyptus (Grandis) & 48.33 & 5.89 & 0.15 & 0.01 & - & 45.13 & 19.35 & - & 0.52 & & 16.93 \\
\hline Pine chips & 52.8 & 3.1 & 0.5 & 0.09 & - & 40.5 & 21.2 & - & 6 & 72.4 & 21.6 \\
\hline Sawdust & 49.8 & 6 & 0.5 & 0.02 & - & 43.7 & 19.83 & - & 1.1 & 84.6 & 14.3 \\
\hline Sawdust & 46.9 & 5.2 & 0.1 & 0.04 & - & 37.8 & 18.14 & - & 2.6 & 76.2 & 13.9 \\
\hline Spruce bark & 53.6 & 6.2 & 0.1 & 0.1 & 0.03 & 40 & 21.57 & - & 3.2 & 73.4 & 23.4 \\
\hline Spruce wood & 52.3 & 6.1 & 0.3 & 0.1 & 0.01 & 41.2 & 20.95 & - & 0.5 & 81.2 & 18.3 \\
\hline \multicolumn{12}{|l|}{ Energy Crops } \\
\hline Miscanthus & 48.4 & 6.3 & 0.3 & 0.1 & 0.13 & 43.3 & 19.6 & 11.5 & 2.8 & 66.8 & 15.9 \\
\hline Poplar & 50.2 & 6.1 & 0.6 & 0.02 & 0.01 & 40.4 & 19.02 & 9.2 & 2.7 & 84.8 & 12.5 \\
\hline Reed canary grass & 46.87 & 6.01 & 0.39 & - & $<0.3$ & 40.66 & 17.15 & - & 5.4 & 76.28 & 14.34 \\
\hline Switchgrass & 46.94 & 6.27 & 0.43 & - & $<0.3$ & 43.26 & 17.82 & - & 4.62 & 73.05 & 15.16 \\
\hline Willow & 49.9 & 5.9 & 0.6 & 0.07 & 0.01 & 41.8 & 19.6 & 13.6 & 1.7 & 82.2 & 16.1 \\
\hline \multicolumn{12}{|l|}{ Agricultural Residues } \\
\hline Alfalfa Stems & 47.2 & 6 & 2.7 & 0.2 & 0.5 & 38.2 & 18.7 & 9.3 & 5.3 & 78.9 & 15.8 \\
\hline Almond Shells (dry) & 49.3 & 6 & 0.8 & 0.04 & 0.01 & 40.6 & 19.5 & 7.8 & 3.3 & 76 & 20.7 \\
\hline Barley Straw & 49.4 & 6.2 & 0.7 & 0.13 & 0.27 & 43.6 & 19.75 & - & 5.3 & 76.2 & 18.5 \\
\hline Pistachio Shells(dry) & 50.2 & 6.3 & 0.7 & 0.2 & 0.01 & 41.1 & 18.2 & - & 1.4 & 81.6 & 17 \\
\hline Rice Husks & 38.8 & 4.8 & 0.5 & 0.05 & 0.1 & 35.5 & 15.8 & 4 & 20.3 & 63.5 & 16.2 \\
\hline Rice Straw & 38.2 & 5.2 & 0.9 & 0.2 & 0.6 & 36.3 & 15.1 & 9 & 18.7 & 65.5 & 15.9 \\
\hline Switchgrass & 46.7 & 5.8 & 0.8 & 0.2 & 0.2 & 37.4 & 18.1 & 13.3 & 9 & 76.7 & 14.3 \\
\hline Wheat Straw & 44.9 & 5.5 & 0.4 & 0.2 & 0.2 & 41.8 & 17.9 & 9.7 & 7 & 75.3 & 17.7 \\
\hline \multicolumn{12}{|l|}{ Imported residues } \\
\hline Olive Cake & 52 & 6.9 & 1.6 & 0.2 & 0.2 & 29.4 & 23 & 6.4 & 10.4 & 66.3 & 16.9 \\
\hline Olive Pits (dry) & 52.8 & 6.7 & 0.5 & 0.05 & 0.04 & 38.3 & 21.6 & 6.1 & 1.7 & 82 & 16.3 \\
\hline Palm Kernel & 46.4 & 6.1 & 38.1 & 2.8 & 0.2 & 38.1 & 19.8 & 5.9 & 3.5 & 80.3 & 10.3 \\
\hline Sugar Cane Bagasse & 48.6 & 5.9 & 0.2 & 0.04 & 0.03 & 42.8 & 19 & 10.4 & 2.4 & 85.6 & 12 \\
\hline \multicolumn{12}{|l|}{ Wastes } \\
\hline Animal Waste & 43.4 & 5.7 & 4.5 & 0.6 & - & 41.1 & - & - & - & - & - \\
\hline Cardboard & 42.2 & 5.6 & 0.2 & 0 & $*$ & 44.8 & 14.5 & 5 & 6.8 & 82.1 & 6.02 \\
\hline Copy paper & 40.8 & 5.7 & 0.21 & 0 & $*$ & 46.6 & 13.8 & 4 & 6.4 & 79.4 & 10.1 \\
\hline HDPE & 85.4 & 11.4 & 0.1 & 0 & - & - & 45.2 & 0.1 & 0.1 & 83.5 & 16.3 \\
\hline LDPE & 84.1 & 12.2 & 0 & 0 & - & - & 45.7 & 1.1 & 0.3 & 98.4 & 0.2 \\
\hline Magazine paper & 35.5 & 4.6 & 0.45 & 0 & $*$ & 36 & 12.3 & 2.1 & 23 & 66.7 & 8.2 \\
\hline Meat and bonemea & 43.4 & 6.4 & 9.2 & 0.4 & 0.3 & & 15.5 & 6 & 20 & 64 & 10 \\
\hline Newspaper & 44.1 & 5.6 & 0.17 & 0 & $*$ & 40.7 & 15.9 & 5.4 & 8.9 & 76.9 & 8.75 \\
\hline Polyamide (PA) & 62.7 & 9.7 & 10.7 & 0 & - & 5.1 & 32.6 & 0 & 0 & 100 & 0 \\
\hline Polycarbonate (PC) & 74.1 & 5.5 & 0.2 & 0 & - & 6.5 & 32.2 & 0 & 0 & 100 & 0 \\
\hline Polyethylene (PE) & 85.7 & 14.3 & - & - & - & - & 44.6 & 0.1 & 0.1 & 97.3 & 2.5 \\
\hline Polyethylene-terephthalate (PET) & 62.8 & 4.3 & 0.07 & - & - & 32.8 & 23.2 & 0.1 & 0 & 97.6 & 2.3 \\
\hline Polypropylene (PP) & 84.4 & - & 0.3 & 0 & - & - & 39.1 & 0.2 & 7.6 & 85.9 & 6.3 \\
\hline Polystyrene (PS) & 90.7 & 7.7 & 0.05 & 0 & - & 1.5 & 42 & 1.2 & 6.5 & 83.4 & 8.9 \\
\hline Polyvinyl chloride (PVC) & 35.9 & 4.4 & 0.1 & 0 & 56.7 & - & 18.1 & 0.99 & 10.4 & 79.1 & 9.6 \\
\hline RDF 1 & 51.3 & 7.5 & 0.8 & 0.21 & 0.6 & 29.7 & 23.1 & 6.9 & 41.5 & 44.6 & 7 \\
\hline RDF 2 (proximate, dry) & 56.3 & 4.7 & 1.7 & 0.13 & 0.6 & 20.2 & 22.4 & 5.2 & 52.8 & 42.6 & 4.6 \\
\hline Recycled paper & 41.9 & 5.5 & 0.27 & 0 & $*$ & 39.5 & 15.2 & 7.5 & 11.9 & 75.8 & 4.81 \\
\hline Scrap tyres & 85.9 & 8 & 0.4 & 1 & 0.1 & 2.3 & 40 & 0.8 & 2.4 & 66.5 & 30.3 \\
\hline Sewage Sludge 1 (dry) & 52 & 6.3 & 6.3 & 3.1 & 0.12 & 32.1 & 21.7 & 6.8 & 32.4 & 59.2 & 8.4 \\
\hline Sewage Sludge 2 & 44.7 & 7.2 & 6.8 & 2.3 & - & 39 & 18.6 & 12.2 & 22.5 & 57 & 8.3 \\
\hline Sewage Sludge 3 & 55.3 & 7.8 & 9.8 & 1.4 & - & 25.8 & 24.6 & - & - & - & - \\
\hline Tetra Pak & 48 & 6.3 & 0.08 & 0 & 0.09 & 39 & 18.5 & 1.3 & 16.1 & 71.9 & 10.7 \\
\hline
\end{tabular}

a.r As received basis

db dry basis

$*$ Range of $0.1-10 \%$; average value $~ 2 \%$ for the paper content of MSW 
Table 2 Example of ash compositions and ash melting characteristics of some woody biomass

\begin{tabular}{|c|c|c|c|c|c|c|c|c|}
\hline & $\begin{array}{l}\text { Pine } \\
{[12]}\end{array}$ & $\begin{array}{c}\text { Pine chips } \\
{[13]}\end{array}$ & $\begin{array}{c}\text { Spruce wood } \\
{[13]}\end{array}$ & $\begin{array}{c}\text { Spruce } \\
\text { bark } \\
{[13]}\end{array}$ & $\begin{array}{c}\text { Eucalyptus } \\
{[12]}\end{array}$ & $\begin{array}{c}\text { Willow } \\
\text { wood } \\
{[14]}\end{array}$ & $\begin{array}{c}\text { Hybrid } \\
\text { Poplar } \\
{[14]}\end{array}$ & $\begin{array}{c}\text { Poplar } \\
{[12]}\end{array}$ \\
\hline \multicolumn{9}{|l|}{ Ash composition (\%) } \\
\hline $\mathrm{SiO}_{2}$ & 52 & 68.18 & 19.3 & 6.13 & 41 & 2.35 & 5.9 & 2.8 \\
\hline $\mathrm{Al}_{2} \mathrm{O}_{3}$ & & 7.04 & 9.4 & 0.68 & & 1.41 & 0.84 & \\
\hline $\mathrm{TiO}_{2}$ & & 0.55 & 0.1 & 0.12 & & 0.05 & 0.3 & \\
\hline $\mathrm{Fe}_{2} \mathrm{O}_{3}$ & & 5.45 & 8.3 & 1.9 & & 0.73 & 1.4 & \\
\hline $\mathrm{CaO}$ & 13 & 7.89 & 17.2 & 72.39 & 18 & 41.2 & 49.92 & 33 \\
\hline $\mathrm{MgO}$ & 4.5 & 2.43 & 1.1 & 4.97 & 4.2 & 2.47 & 18.4 & 3.7 \\
\hline $\mathrm{Na}_{2} \mathrm{O}$ & 1.9 & 1.2 & 0.5 & 2.02 & 1.9 & 0.94 & 0.13 & 0.14 \\
\hline $\mathrm{K}_{2} \mathrm{O}$ & 7.9 & 4.51 & 9.6 & 7.22 & 8.7 & 15 & 9.64 & 18 \\
\hline $\mathrm{SO}_{3}$ & & 1.19 & 2.6 & 1.88 & & 1.83 & 2.04 & \\
\hline $\mathrm{P}_{2} \mathrm{O}_{5}$ & & 1.56 & 0.1 & 0.12 & & 7.4 & 1.34 & \\
\hline \multicolumn{9}{|l|}{ Slagging and fouling indices } \\
\hline Alkali index (kg alkali/GJ) & & 0.16 & 0.02 & 0.14 & & 0.14 & 0.14 & \\
\hline Base to acid ratio & & 0.28 & 1.27 & 12.77 & & 15.84 & 11.29 & \\
\hline Base percentage $(\%)$ & & 21.48 & 36.7 & 88.5 & & 60.34 & 79.49 & \\
\hline \multicolumn{9}{|l|}{ Ash fusion temperatures $\left({ }^{\circ} \mathrm{C}\right)$} \\
\hline Deformation & 1190 & & & & 1160 & \multicolumn{2}{|c|}{ lapses at 1190} & $>1400$ \\
\hline Hemisphere & 1220 & & & & 1190 & & & $>1400$ \\
\hline Flow & 1280 & & & & 1230 & & & $>1400$ \\
\hline
\end{tabular}

Table 3 Example of ash compositions and ash melting characteristics of some herbaceous biomass and straws

\begin{tabular}{|c|c|c|c|c|c|c|c|c|}
\hline & $\begin{array}{c}\text { Miscanthus } \\
{[15]} \\
\end{array}$ & $\begin{array}{c}\text { Switchgrass } \\
{[14]} \\
\end{array}$ & $\begin{array}{c}\text { Switchgrass } \\
{[14]}\end{array}$ & $\begin{array}{c}\text { Reed } \\
\text { canary } \\
\text { grass } \\
{[14]}\end{array}$ & $\begin{array}{c}\text { Wheat } \\
\text { straw } \\
{[14]}\end{array}$ & $\begin{array}{c}\text { Barley } \\
\text { Straw } \\
{[16]}\end{array}$ & $\begin{array}{c}\text { Barley } \\
\text { straw } \\
{[13]}\end{array}$ & $\begin{array}{c}\text { Rape straw } \\
{[13]}\end{array}$ \\
\hline \multicolumn{9}{|l|}{ Ash composition (\%) } \\
\hline $\mathrm{SiO}_{2}$ & 33.8 & 61.3 & 65.18 & 75 & 55.32 & & 50.78 & 40.8 \\
\hline $\mathrm{Al}_{2} \mathrm{O}_{3}$ & 0.35 & 0.85 & 4.51 & 0.37 & 1.88 & & 0.67 & 5.45 \\
\hline $\mathrm{TiO}_{2}$ & 0 & 0.09 & 0.24 & & 0.08 & & 0.08 & 0.29 \\
\hline $\mathrm{Fe}_{2} \mathrm{O}_{3}$ & 0.31 & 0.93 & 2.03 & 0.04 & 0.73 & & 0.95 & 2 \\
\hline $\mathrm{CaO}$ & 6.2 & 16.5 & 5.6 & 9.13 & 6.14 & & 9.89 & 30.68 \\
\hline $\mathrm{MgO}$ & 6.55 & 2.82 & 3 & 1.95 & 1.06 & & 2.87 & 2 \\
\hline $\mathrm{Na}_{2} \mathrm{O}$ & 0.73 & 0.75 & 0.58 & 0.25 & 1.71 & & 1.39 & 0.44 \\
\hline $\mathrm{K}_{2} \mathrm{O}$ & 37.9 & 2.76 & 11.6 & 2.87 & 25.6 & & 28.18 & 13.45 \\
\hline $\mathrm{SO}_{3}$ & 5.54 & 2.56 & 0.44 & 1.82 & 4.4 & & 2.22 & 2.67 \\
\hline $\mathrm{P}_{2} \mathrm{O}_{5}$ & 2.01 & 3.27 & 4.5 & 4.09 & 1.26 & & 2.97 & 2.22 \\
\hline \multicolumn{9}{|l|}{ Slagging and fouling indices } \\
\hline Alkali index (kg alkali/GJ) & 0.26 & 0.09 & 0.6 & 0.1 & 1.07 & & 0.79 & 0.32 \\
\hline Base to acid ratio & 1.51 & 0.38 & 0.33 & 0.19 & 0.62 & & 0.84 & 1.04 \\
\hline Base percentage $(\%)$ & 51.7 & 23.76 & 22.81 & 14.24 & 35.24 & & 43.28 & 48.57 \\
\hline \multicolumn{9}{|l|}{ Ash fusion temperatures $\left({ }^{\circ} \mathrm{C}\right)$} \\
\hline Deformation & 920 & & & & 850 & 925 & & \\
\hline Hemisphere & 1070 & & & & 1120 & $\mathrm{n} / \mathrm{a}$ & & \\
\hline Flow & 1110 & & & & 1320 & 1100 & & \\
\hline
\end{tabular}


Table 4 Example of ash compositions and ash melting characteristics of some residues and wastes

\begin{tabular}{|c|c|c|c|c|c|c|c|c|c|c|}
\hline & $\begin{array}{c}\text { Sugar cane } \\
\text { bagasse } \\
{[12]}\end{array}$ & $\begin{array}{c}\text { PKE } \\
{[4]}\end{array}$ & $\begin{array}{c}\text { Olive residue } \\
\text { A [4] }\end{array}$ & $\begin{array}{c}\text { Olive } \\
\text { residue C } \\
{[4]}\end{array}$ & $\begin{array}{c}\text { Sunflower } \\
\text { [12] }\end{array}$ & $\begin{array}{c}\text { Sunflower } \\
\text { shell } \\
{[17]}\end{array}$ & $\begin{array}{c}\text { Sunflower } \\
\text { husk } \\
{[13]}\end{array}$ & $\begin{array}{c}\text { Sawdust } \\
\text { [13] }\end{array}$ & $\begin{array}{l}\text { Furniture } \\
\text { waste } \\
{[18]}\end{array}$ & $\begin{array}{l}\text { Forest } \\
\text { residue } \\
{[18]}\end{array}$ \\
\hline \multicolumn{11}{|l|}{ Ash composition (\%) } \\
\hline $\mathrm{SiO}_{2}$ & 46.61 & 16.51 & 21.1 & 67.4 & 11 & 29.3 & 23.66 & 26.17 & 57.62 & 17.78 \\
\hline $\mathrm{Al}_{2} \mathrm{O}_{3}$ & 17.69 & 0.87 & 1.94 & 2.74 & & 2.9 & 8.75 & 4.53 & 12.23 & 3.55 \\
\hline $\mathrm{TiO}_{2}$ & 2.63 & $\mathrm{n} / \mathrm{a}$ & & & & 0.1 & 0.15 & 0.4 & 0.5 & 0.5 \\
\hline $\mathrm{Fe}_{2} \mathrm{O}_{3}$ & 14.14 & 5.7 & 2.14 & 5.29 & & 2.1 & 4.27 & 1.82 & 5.63 & 1.58 \\
\hline $\mathrm{CaO}$ & 4.47 & 11.9 & 15.44 & 19.49 & 17 & 15.8 & 15.31 & 44.11 & 13.89 & 45.46 \\
\hline $\mathrm{MgO}$ & 3.33 & 11.51 & 5.78 & 5.25 & 3.8 & 6.1 & 7.33 & 5.34 & 3.28 & 7.48 \\
\hline $\mathrm{Na}_{2} \mathrm{O}$ & 0.79 & 0.41 & 0.47 & 0.35 & 0.55 & 1.5 & 0.8 & 2.48 & 2.36 & 2.13 \\
\hline $\mathrm{K}_{2} \mathrm{O}$ & 0.15 & 21.43 & 31.04 & 4.41 & 24 & 35.6 & 28.53 & 10.83 & 3.77 & 8.52 \\
\hline $\mathrm{SO}_{3}$ & 2.08 & $\mathrm{n} / \mathrm{a}$ & $\mathrm{n} / \mathrm{a}$ & $\mathrm{n} / \mathrm{a}$ & & 1.3 & 4.07 & 2.05 & 1 & 2.78 \\
\hline $\mathrm{P}_{2} \mathrm{O}_{5}$ & 2.72 & $\mathrm{n} / \mathrm{a}$ & $\mathrm{n} / \mathrm{a}$ & $\mathrm{n} / \mathrm{a}$ & & 4.8 & 7.13 & 1.82 & 0.5 & 0.44 \\
\hline \multicolumn{11}{|l|}{ Slagging and fouling indices } \\
\hline Alkali index (kg alkali/GJ) & 0.06 & 0.48 & 1.57 & 0.69 & & 0.78 & 0.45 & 0.07 & 0.1 & 0.2 \\
\hline Base to acid ratio & 0.36 & 2.93 & 2.38 & 0.5 & & 1.89 & 1.73 & 2.08 & 0.41 & 2.99 \\
\hline Base percentage $(\%)$ & 22.88 & 50.94 & 54.87 & 34.79 & & 61.1 & 56.24 & 64.58 & 28.93 & 65.17 \\
\hline \multicolumn{11}{|l|}{ Ash fusion temperatures $\left({ }^{\circ} \mathrm{C}\right)$} \\
\hline Deformation & & 1070 & 1080 & & 740 & & & 1270 & & \\
\hline Hemisphere & & 1140 & 1350 & & 1360 & & & 1410 & & \\
\hline Flow & & 1180 & 1360 & & 1390 & & & 1430 & & \\
\hline
\end{tabular}

Table 5 Inductively Coupled Plasma-Mass Spectrometry ICP-MS determination of trace elements in a selection of biomass (expressed as ppm, on as received basis) [11]

\begin{tabular}{|c|c|c|c|c|c|c|c|c|c|}
\hline $\begin{array}{l}\text { Trace elements } \\
\quad(\text { ppm db) }\end{array}$ & $\begin{array}{l}\text { Olive } \\
\text { residue }\end{array}$ & $\begin{array}{l}\text { Hazeln } \\
\text { ut shell }\end{array}$ & $\begin{array}{l}\text { Cotton } \\
\text { residue }\end{array}$ & $\begin{array}{l}\text { Straw } \\
(\text { ar) }\end{array}$ & $\begin{array}{l}\text { Wood- } \\
\text { bark } \\
\text { (ar) }\end{array}$ & RDF & $\begin{array}{l}\text { Sewage } \\
\text { Sludge }\end{array}$ & $\begin{array}{l}\text { Waste wood } \\
\text { Typical Range }\end{array}$ & $\begin{array}{c}\text { Recommendation } \\
\text { for quality sorted } \\
\text { waste wood }\end{array}$ \\
\hline As & 0.72 & 0.29 & 0.12 & $<0.10$ & 0.44 & 5 & 10 & & \\
\hline $\mathrm{Be}$ & 14.7 & 18.2 & 2.27 & $<0.10$ & 0.07 & & & & \\
\hline $\mathrm{Cd}$ & 0.017 & 0.04 & 0.022 & $<0.15$ & 0.2 & $<1$ & 2 & $0.3-3.0$ & $<1.0$ \\
\hline $\mathrm{Co}$ & 0.527 & 0.38 & 0.472 & & & $<2$ & 3 & & \\
\hline $\mathrm{Cr}$ & 8.98 & 1.82 & 2.23 & 2.49 & 26 & 8 & 62 & & \\
\hline $\mathrm{Cu}$ & 15.3 & 7.9 & 11.3 & 3.16 & 87.3 & 35 & 829 & & \\
\hline $\mathrm{Fe}$ & & & & & & & & & \\
\hline $\mathrm{Hg}$ & & & & 0.009 & 0.034 & $<2$ & $<2$ & Up to 0.4 & $<0.3$ \\
\hline $\mathrm{Li}$ & 0.776 & 0.118 & 0.136 & & & & & & \\
\hline $\mathrm{Mn}$ & 26.2 & 106.3 & 17.1 & 20.4 & 414 & & & & \\
\hline Mo & 0.25 & 0.13 & 1.61 & 0.42 & 1.26 & & & & \\
\hline $\mathrm{Ni}$ & 5.1 & 1.97 & 2.8 & 0.9 & 10 & 2 & 32 & & \\
\hline $\mathrm{P}$ & 907 & 146 & 7361 & & & & & & \\
\hline $\mathrm{Pb}$ & 3.24 & 3.53 & 1.22 & 2.64 & 3.06 & 50 & 211 & $50-400$ & $<100$ \\
\hline $\mathrm{Sb}$ & 0.144 & 0.066 & 0.028 & & & & & & \\
\hline $\mathrm{Se}$ & $<0.18$ & $<0.18$ & $<0.18$ & $<0.20$ & $<0.80$ & & & & \\
\hline Sn & 0.616 & 0.11 & 1.455 & & & & & & \\
\hline $\mathrm{Tl}$ & 0.016 & $<0.003$ & $<0.003$ & 0.002 & 0.086 & & & & \\
\hline $\mathrm{V}$ & 2.91 & 1.05 & 5.3 & 0.82 & 2.81 & & & & \\
\hline $\mathrm{Zn}$ & 14.8 & 22.8 & 32.2 & 30.9 & 150 & 85 & 567 & $200-1200$ & $<200$ \\
\hline
\end{tabular}

ppm parts per million

a.r as received

db dry basis 
The impact of the different mix of inorganics in biomass compared to typical coal ash composition is well documented (e.g. [12-14]). Different elements have different volatility; particularly volatile are the alkali chlorides. Gas phase reactions can lead to alkali sulphates, and these together with the chlorides are key species responsible in slagging, fouling and corrosions. Different ash chemistry leads to liquid or sticky ash particles with also form furnace deposits.

Biomass ash often has a low melting temperature leading to slagging and fouling, depending on the temperature and site that deposition occurs. Slagging is associated with the fusion and sintering of ash particles in the high temperature (radiative sections) of the boiler. Particles entrained in the flue gas impinge on boiler tubes and walls and can adhere depending upon the state of the particle and the surface in question. If either the particle or the surface is molten or sticky then the particle sticks by inertial impaction [15]. The temperature at which the ash softens is determined from the ash fusion test, and some measurements of this are given in Tables 2-4. Initial deposition rate is slow onto the clean and relatively cool surface, but it increases as the surface deposit gets thicker and the outside surface temperature increases. The base/acid ratio $\left(\mathrm{R}_{\mathrm{b} / \mathrm{a}}\right)$ is also a good indication of the ash fusibility and some values of this are also given in Tables 2-4. In the $\mathrm{R}_{\mathrm{b} / \mathrm{a}}$, $\mathrm{b}$ indicates the sum of the basic oxides in the ash while a indicates the sum of the acidic oxides in the ash. It is given by

$$
\mathrm{R}_{\mathrm{b} / \mathrm{a}}=\frac{\%\left(\mathrm{Fe}_{2} \mathrm{O}_{3}+\mathrm{CaO}+\mathrm{MgO}+\mathrm{Na}_{2} \mathrm{O}+\mathrm{K}_{2} \mathrm{O}\right)}{\%\left(\mathrm{SiO}_{2}+\mathrm{Al}_{2} \mathrm{O}_{3}+\mathrm{TiO}_{2}\right.}
$$

The correlation between ash melting temperature and base-acid ratio for coal tends to be parabolic with a minimum of 0.75 . The ratio is less well validated for biomass fuels, but it is likely that the eutectic appears at lower base/acid ratio values [16]. Thus, normally a low melting temperature ash would have a $\mathrm{R}_{\mathrm{b} / \mathrm{a}}$ of 0.4-0.6 [17]. Phosphorus is not included in the $\mathrm{R}_{\mathrm{b} / \mathrm{a}}$ ratio since it was developed for coals originally (with low $\mathrm{P}$ content).

While considering the slagging in boilers, $\mathrm{Fe}_{2} \mathrm{O}_{3}$ in the fly ash is considered to be basic [16] but in the concrete industry it is considered to be acidic. In the case of biomass ash, the concentration of $\mathrm{Fe}_{2} \mathrm{O}_{3}$ is fairly low and hence has no significant effect on the slagging in boilers.

The alkali metals volatilise at low temperatures forming gaseous chlorides, hydroxides and sulphates dependent upon the temperature of the gas phase $[19,20]$. The fate of these gas phase species is multifaceted: They can deposit onto small ash particles making a sticky coating at high temperature and encouraging these particles to stick to furnace walls and superheater tubes. The deposits can become very thick such that a temperature gradient forms across them and the deposits start to form different sintered, strong phases which are very difficult to remove, and lower the efficiency of the boiler $[12,15]$. The alkali vapours might pass to the convective section of the boiler where they condense and foul the heat exchanger tubes. This can result in corrosion, as redox reactions shuttle chloride through the scale layer of the boiler tubes which then reacts with the steel [12]. Some alkali vapours may pass through the furnace entirely and form aerosol particles which are not as efficiently captured by dust removal systems.

Other indices [21], also derived from correlations of coal ash behaviour, include the slagging index, $R_{s}$, and the ratio-slag viscosity index $S_{\mathrm{i}}$. 


$$
R_{S}=\% S(d r y)\left(\frac{B}{A}\right)
$$

Here $\mathrm{R}_{\mathrm{s}}<0.6$ indicates low slagging propensity, $\mathrm{R}_{\mathrm{s}}=0.6-2.0$ indicates medium slagging propensity, $R_{s}=2.0-2.6$ indicates high slagging risk, and $R_{s}>2.6$ indicates extremely high slagging risk.

$$
S_{i}(\%)=\left(\frac{\mathrm{SiO}_{2}}{\mathrm{SiO}_{2}+\mathrm{Fe}_{2} \mathrm{O}_{3}+\mathrm{CaO}+\mathrm{MgO}}\right) \times 100
$$

A high ratio-slag viscosity index indicates a high viscosity and therefore a low risk of slagging. Indicators are as follows: $S_{\mathrm{i}}>72=$ low slagging risk; $72 \geq S_{\mathrm{i}}>65=$ medium slagging risk; $\mathrm{S}_{\mathrm{i}} \leq 65=$ high slagging risk.

Fouling is ash deposition in the convective section of the boiler and can be indicated by the alkali index (AI):

$$
A I=\frac{1}{G C V} F_{a s h}\left(F_{K 2 O}+F_{N a 2 O}\right)
$$

Where GCV is expressed in $\mathrm{GJkg}^{-1}, \mathrm{~F}_{\text {ash }}$ is the mass fraction of ash in the fuel (dry basis), and $\mathrm{F}_{\mathrm{K} 2 \mathrm{O}}$ and $\mathrm{F}_{\mathrm{Na} 2 \mathrm{O}}$ are the mass fractions of $\mathrm{K}_{2} \mathrm{O}$ and $\mathrm{Na}_{2} \mathrm{O}$ in the ash. It has been suggested that above $0.17 \mathrm{~kg}$ alkali $\mathrm{GJ}^{-1}$ fouling is probable, and above $0.34 \mathrm{~kg} \mathrm{GJ}^{-1}$ fouling is virtually certain to occur (12). Some calculated fouling indices are also given in Tables 2-4, and Fig 1 displays some of these also.

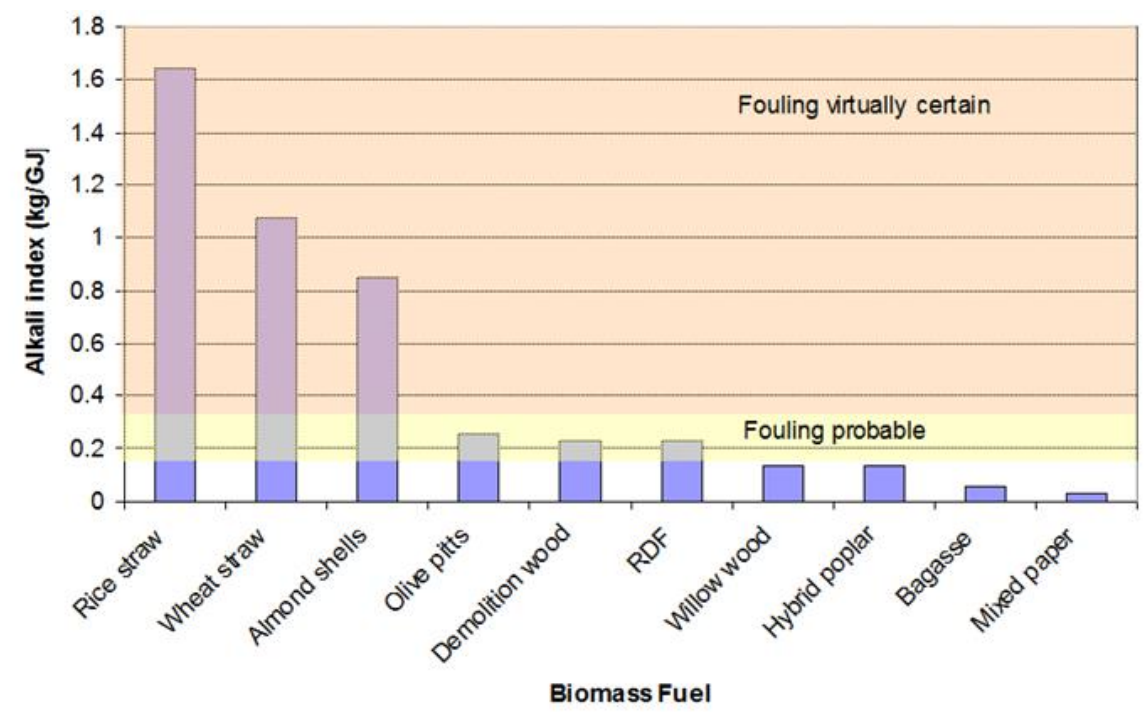

Fig 1 Calculated alkali indices of some biomass fuels 
The Fouling Index is given by:

$$
F_{u}=\frac{B}{A}\left(\mathrm{Na}_{2} \mathrm{O}+\mathrm{K}_{2} \mathrm{O}\right)
$$

Where $\mathrm{F}_{\mathrm{u}}<0.6=$ low fouling risk, $0.6<\mathrm{F}_{\mathrm{u}} \leq 40=$ high fouling risk, $\mathrm{F}_{\mathrm{u}}>40$ extremely high sintering tendencies are implied [21].

The ash fusion test is a standard test developed to describe the melting behaviour of biomass ashes. A test piece made from a prepared ash is heated at constant rate and with continuous observation. Four characteristic temperatures are recorded from changes in the test piece shape, namely the shrinkage temperature (ST), deformation temperature (DT), hemisphere temperature (HT) and flow temperature (FT).

\section{Biomass Emissions before and after pre-treatment 3.1 Emissions from Biomass Combustion}

Biomass contains volatile trace metals which can also pass to the flue and be emitted to atmosphere. This is a particularly important consideration for Waste Incineration Directive (WID) compliant plant where fuels might have higher levels of heavy trace metals. Trace metals are classified according to their volatility as indicated in Fig 2. There is overlap between the groups, and some studies report different partitioning to others. This is not surprising since partitioning is influenced by chemical interactions as well as operating conditions. E.g. chlorine increases volatility of trace metals through the formation of metal chlorides.

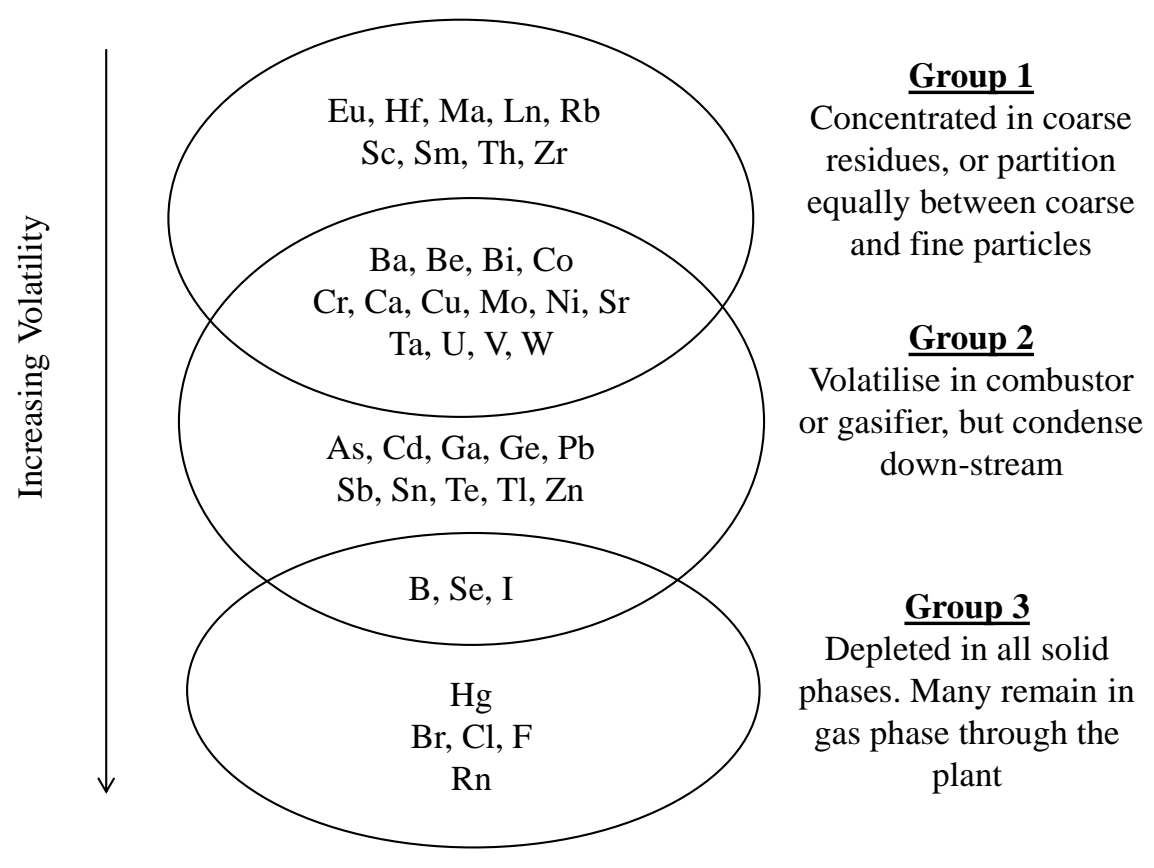

Fig 2 Classification of trace elements by their partitioning into groups of different volatility during combustion and gasification (Adapted from [22]) 
Apart from inorganic emissions, organic emissions can be of concern, particularly for small scale boilers [23]. Biomass degrades, upon heating to produce volatiles and tars which can react further to produce polyaromatic hydrocarbons $(\mathrm{PAH})$ and soot. This can proceed by a number of routes depending upon the temperature, residence time and the local stoichiometry. During the combustion of the biomass both pyrolysis and oxidative pyrolysis of the biomass components occurs with the release of tars and vapours. The initial products obtained are a function of the composition of the biomass, the water content and the level of excess air. The extent of incomplete combustion and hence the level of the emissions can be controlled by the design features ensuring mixing of the fuel and air [24]. If the temperature is low (below $\sim 700^{\circ} \mathrm{C}$ ) as might be the case in small cook stoves and units based on smouldering combustion, and there is poor mixing then compounds in the bottom half of Figure 2 dominate in the smoke. At higher temperature (above $\sim 900^{\circ} \mathrm{C}$ ) which would be the case in larger domestic combustors and industrial furnaces, emissions of pyrolysis products decrease and compounds in the top half of Fig 2 become more dominant.

\subsection{Approaches to mitigate deposition/emission problems}

A number of approaches have been explored to mitigate the deposition/corrosion and emission problems during combustion. These include:

1. The use of blends to modify ash behaviour and help retain volatile metals in the ash. This approach has also been used to adjust the $\mathrm{S} / \mathrm{Cl}$ ratio to help limit corrosion [25].

2. The use of additives that seek to change the chemical composition of the ash and so the melting temperature, and potential for release of volatile components. Typical additives are Al-Si-based (e.g. kaolinite), S-based (e.g. ammonium sulphate), P-based, or Ca-based [26].

3. Lowering the concentration of key elements before the fuel enters the boiler to mitigate the ash and emission problems using pre-treatment methods. This can be done by pre-treatment via washing in order to upgrade low-grade biomass for heat/electricity generation.

Inorganics in biomass can be categorised into four groups [17]:

1. Dissolved salts that are precipitated during the drying process and include the anions and cations dissolved in the plant fluids, typically, $\mathrm{K}^{+}, \mathrm{Na}^{+}, \mathrm{Ca}^{2+}, \mathrm{Cl}^{-}, \mathrm{HPO}_{4}{ }^{2-}, \mathrm{H}_{2} \mathrm{PO}_{4}{ }^{-}$, $\mathrm{SO}^{2-}$. These salts can be redissolved and removed during water washing.

2. Organically-bound matter that are mainly metal cations that are associated with the organic polymers and include $\mathrm{K}, \mathrm{Na}, \mathrm{Mn}, \mathrm{Ca}, \mathrm{Mg}, \mathrm{Fe}$, and $\mathrm{Al}$. These are capable of undergoing ion exchange in ammonium acetate solutions; Sulphur and nitrogen are associated with organic matter via covalent bonds, such as in amino acids, proteins etc. These are insoluble or only slightly soluble in water solutions. Phosphorus can be present in organic forms which may be partly soluble in acids. Chlorine may be present in organic form, especially in waste-derived fuels containing PVC.

3. Included minerals that are mineral naturally deposited during the plant growth. They include silica and different calcium oxalates. These have typically low solubility in water, but the calcium salts become more soluble in acid solutions.

4. Excluded minerals that arise from soil and foreign particles attached to the biomass. Soil material will not dissolve easily although may rinse off the fuel. This category also includes contaminants associated with waste wood, which might include PVC, 
paints, glues, and preservatives. The inorganics associated with these contaminants have varying solubility depending upon their form.

There is extensive literature concerned with leaching/washing of biomass. Several authors have been interested in characterising the inorganics based on their ease of leaching using successive treatment in water, ammonium acetate and finally acid. Different $\mathrm{pH}$ solvents leach different groups of inorganics in a process known as selective leaching [27] There has been some success in ranking fuels in terms of their likelihood to form deposits based on the amount of easily leached (generally volatile) species [28].

Table 6 summarises some of the literature concerning leaching of different elements in water. Miles [29] also categorised inorganics into four types:

1. Refractories ( $\mathrm{Si}, \mathrm{Ti}, \mathrm{Al})$ with little or no solubility.

2. Alkali and alkaline earth elements $(\mathrm{Na}, \mathrm{K}, \mathrm{Ca}, \mathrm{Mg})$ with varying degrees of solubility

3. Non-metallic elements $(\mathrm{Cl}, \mathrm{S}, \mathrm{P})$

4. Iron

Miles and his team studied a wide range of fuels at three different laboratories following identical procedures (16 h, hot water). Fuels included almond hulls, almond shells, urban waste wood fuel blended with wheat straw, urban wood fuel blended with almond shells, olive pits, rice straw, switchgrass, non-recyclable paper and wheat straw. They found that the refractory group $(\mathrm{Si}, \mathrm{Ti}, \mathrm{Al})$ are essentially insoluble in all the fuels investigated. The alkali metals are highly soluble in water and the authors propose that this indicates a high mobility and susceptibility to vaporisation during combustion. 50-90\% of the potassium was leached through water washing of the "clean fuels". Less potassium $(\sim 35 \%)$ was removed from the non-recyclable paper, which may be a consequence of the form it is in (i.e. clays in the glossy print). In general, sodium was removed in slightly lower percentages and there was more variability depending on fuel type. In most fuels studied, at least $40 \%$ of the sodium was leached by water washing. The alkaline earth metals $(\mathrm{Ca}, \mathrm{Mg})$ are less soluble in water, with $\mathrm{Mg}$ being leached to a greater extent than $\mathrm{Ca}$ in all fuels studied. Most fuels exhibited $<20 \%$ $\mathrm{Ca}$ removal, the exceptions being almond hulls ( 40\%) and wheat straw ( 30\%). $\mathrm{Mg}$ leaching was more variable; almond hulls, almond shells, rice straw and wheat straw all showed a high (nearly 50\%) removal of $\mathrm{Mg}$, and other fuels were generally less than $20 \%$ removal.

Non-metallic elements $(\mathrm{Cl}, \mathrm{P}$ and $\mathrm{S})$ were also investigated and results are summarised in Table 6. \% removal was strongly dependent on fuel type. Chlorine was easily removed by water washing from all the fuels except non-recyclable paper (25\% removed). Sulphur is present in trace amounts in most fuels but was generally found to be in soluble form in wheat straw, rice straw, almond hulls and almond shells. Lower solubility was seen for the sulphur in the woody biomass fuels. Phosphorus showed high solubility ( $>50 \%$ removed) from the agricultural residues and straws. Less $(<25 \%)$ was removed from the urban waste wood.

Saddawi et al also studied leaching in water at room temperature for four chipped fuels (Miscanthus, wheat straw, willow, and eucalyptus) [30]. Similar findings were reported - i.e. alkali metals and chloride show high solubility. Magnesium is more soluble than calcium, but both are less easy to remove than the alkali metals. The efficiency of removal of phosphorus and sulphur appears to be very fuel dependent. 
The group at Abo Akademi University have also been very active in this area and have published a number of studies [e.g. [17, 31]]. General conclusions are that potassium, sodium, chloride and phosphorus show high potential for water leaching from woody biomass (spruce, pine, birch and aspen) and agricultural residues (straws, bagasse, seeds, hulls etc.). Some calcium and magnesium can also be leached.

Specific studies on the effect of water temperature on leaching appear to be limited. Deng and co-workers [32] studied six biomass fuels, wheat straw, rice straw, corn stalk, cotton stalk, candlenut wood and rice hull. These were soaked in water for $3 \mathrm{~h}$ at 30,60 or $90^{\circ} \mathrm{C}$ and analysed for ash composition before and after treatment. The results, summarized in Table 7 , indicate that a positive effect is observed with increasing temperature; ash weight percent decreases for all fuels as the water temperature increases. This appears to mostly arise from the removal of silica from the biomass since the efficiency of removal of this species appears receptive to elevated water temperature. The highly soluble inorganics, $\mathrm{K}$ and $\mathrm{Cl}$ are removed in high percentages at all water temperatures, but higher temperature was more advantageous for the wood fuel studied, where a significant improvement in $\mathrm{K}$ (from $70 \%$ to $85 \%$ removed) and a small improvement in $\mathrm{Cl}$ removal is observed. It is likely that the $\mathrm{K}$ and $\mathrm{Cl}$ are so soluble and accessible in the grassy biomass and residues that higher temperature produces no added benefit. Also, it should be noted that small particle sizes of fuels were used and this is likely to improve efficiencies of removal also. The effect of temperature may be more marked for larger particle sizes, but this is an area for further study.

Jenkins [27] did the early work on the influence of washing on the inorganics in straws. Their results are summarised in Table 6 and in Fig 3. Other fuels were investigated but only results for wheat straw and particularly rice straw are reported in detail. Even just spraying of the rice straw was seen to give rise to a $40-50 \%$ reduction in $\mathrm{K}, \mathrm{P}$, and $\mathrm{Cl}$ and a $20 \%$ reduction in $\mathrm{Na}$. Soaking produced dramatic results for both rice straw and wheat straw with $80-90 \%$ removal of $\mathrm{Cl}, \mathrm{Na}, \mathrm{P}$, and $\mathrm{K}$ observed together with a $70 \%$ reduction in $\mathrm{S}$ content. Surprisingly, very similar results were observed for rain-washed rice straw after $65 \mathrm{~mm}$ of cumulative rain fall.

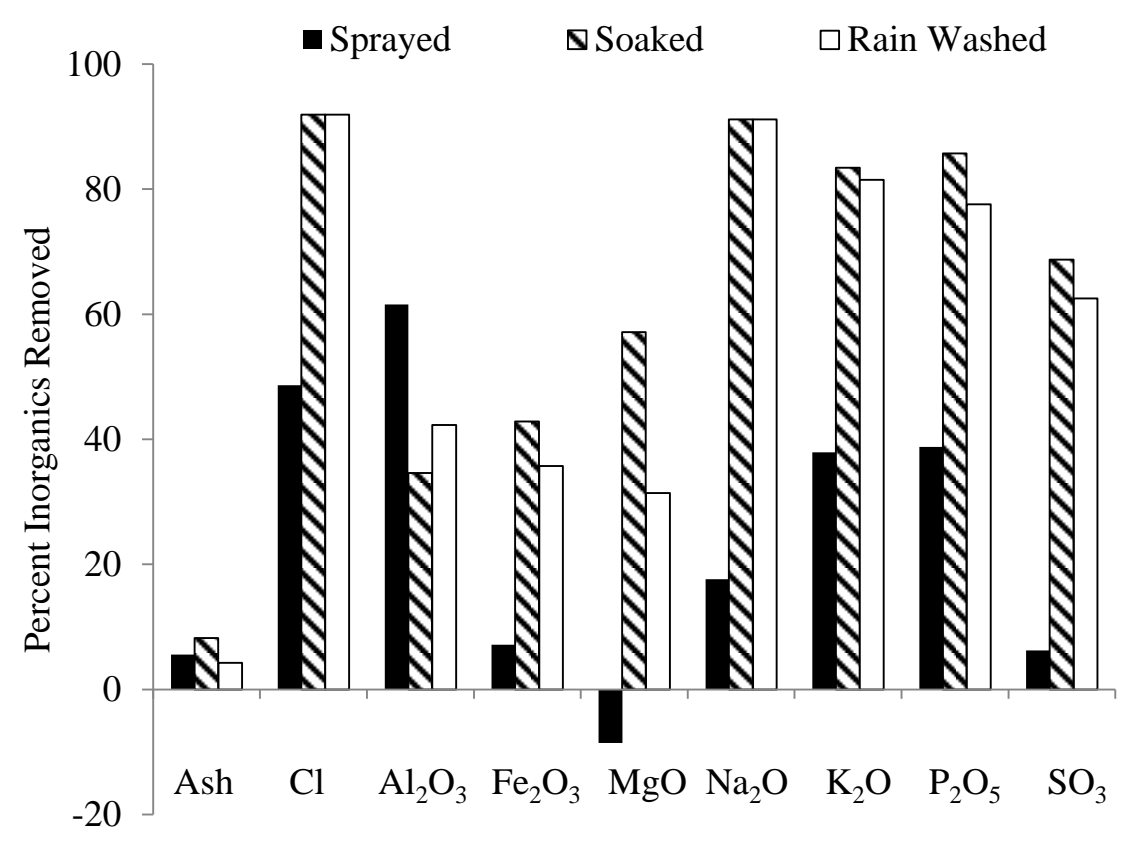


Fig 3 Influence of different washing approaches on the inorganics in rice straw [27].

Fig 3 indicates the reduction in chlorine after water washing. This together with the results summarised in Table 6 indicate the high solubility of chlorine and ease of removal by water washing most biomass. Since chlorine content is almost monotonically related to $\mathrm{HCl}$ emission during combustion, it is clear that water washing will be beneficial for $\mathrm{HCl}$ emissions and significantly reducing chlorine-mediated corrosion.

There have been few studies of the influence of time on the leaching process. Liaw and $\mathrm{Wu}$ [33] used a batch reactor at room temperature to leach Eucalyptus Loxophleba (mallee) samples $(150-250 \mu \mathrm{m})$ and monitored for sodium, potassium, magnesium calcium and chloride as a function of time. Results were compared with a continuous flow reactor system and are summarised in Figure 4 and Table 6. Greater than 90\% removal of potassium, sodium and chloride were observed within the first few minutes, equilibrium appears to be reached in less than 5 minutes.

Chromated Copper Arsenate (CCA) - contaminated wood: Chromium, copper and arsenic contamination in waste wood arises from preservatives used to give high durability to fences, decking, poles etc. by protecting insect and fungus attacks. Eventually, this wood makes its way into the waste wood stream, and can lead to leaching and dispersion if it is disposed of in landfills [34-36]. Furthermore combustion of CCA-treated wood risks the release of volatile metals into the atmosphere and/or leaching of these metals from the resulting ash [37-39]. Most studies (e.g. [40], Table 6) have found these elements to be highly mobile and can be leached through water washing. Often this is followed by approaches for capturing the leached elements from the leachate for disposal. Clearly, pre-treatment via water washing is expected to have very positive impacts on the emission of volatile trace metals from the flue during combustion. However, if the wood is high in these elements then remediation approaches for the leachate will need to be considered [40]. 
Table 6 Success of leaching on \% removal of different inorganic elements

\begin{tabular}{|c|c|c|c|c|c|c|}
\hline Fuel & Species & Solvent & Temp, Time & Size & $\%$ removed & Ref \\
\hline $\begin{array}{l}\text { Range of urban } \\
\text { wastes, agricultural } \\
\text { residues, } \\
\text { grasses and straws }\end{array}$ & $\mathrm{Si}, \mathrm{Ti}, \mathrm{Al}$ & Water & $\begin{array}{l}\text { Hot plate, } \\
\text { not boiling, } \\
16 \mathrm{~h} \text {, soaked }\end{array}$ & $<60$ mesh & Very low or not soluble & [29] \\
\hline $\begin{array}{l}\text { Range of urban } \\
\text { wastes, agricultural } \\
\text { residues, } \\
\text { grasses and straws }\end{array}$ & $\mathrm{K}, \mathrm{Na}, \mathrm{Ca}, \mathrm{Mg}$ & Water & $\begin{array}{l}\text { Hot plate, } \\
\text { not boiling, } \\
16 \mathrm{~h} \text {, soaked }\end{array}$ & $<60$ mesh & $50-90 \% \mathrm{~K}, 10-90 \% \mathrm{Na}, 5-35 \% \mathrm{Ca}, 5-60 \% \mathrm{Mg}$ & [29] \\
\hline $\begin{array}{l}\text { Range of urban } \\
\text { wastes, agricultural } \\
\text { residues, wood fuels, } \\
\text { grasses and straws }\end{array}$ & $\mathrm{Cl}, \mathrm{S}, \mathrm{P}$ & Water & $\begin{array}{l}\text { Hot plate, } \\
\text { not boiling, } \\
16 \mathrm{~h} \text {, soaked }\end{array}$ & $<60$ mesh & $30-100 \% \mathrm{Cl}, 0-95 \% \mathrm{~S}, 10-80 \% \mathrm{P}$ & [29] \\
\hline $\begin{array}{l}\text { Range of urban } \\
\text { wastes, agricultural } \\
\text { residues, } \\
\text { grasses and straws }\end{array}$ & $\mathrm{Fe}$ & Water & $\begin{array}{l}\text { Hot plate, } \\
\text { not boiling, } \\
16 \mathrm{~h} \text {, soaked }\end{array}$ & $<60$ mesh & $0-30 \% \mathrm{Fe}$ & [29] \\
\hline SRC Willow & $\begin{array}{l}\mathrm{Na}, \quad \mathrm{K}, \quad \mathrm{Ca} \\
\mathrm{Mg}, \mathrm{P}, \mathrm{S}, \mathrm{Cl}\end{array}$ & Water & $\begin{array}{l}\text { Room temp, } \\
\text { 20h stirred }\end{array}$ & 2-4 cm chip & $\begin{array}{l}30 \% \mathrm{Na}, 46 \% \mathrm{~K}, 14 \% \mathrm{Mg}, 3 \% \mathrm{Ca}, 56 \% \mathrm{PO}_{4}^{3-}, 10 \% \\
\mathrm{SO}_{4}^{2-} \text {, up to } 100 \% \mathrm{Cl}\end{array}$ & [30] \\
\hline Eucalyptus & $\begin{array}{l}\mathrm{Na}, \quad \mathrm{K}, \quad \mathrm{Ca} \\
\mathrm{Mg}, \mathrm{P}, \mathrm{S}, \mathrm{Cl}\end{array}$ & Water & $\begin{array}{l}\text { Room temp, } \\
\text { 20h stirred }\end{array}$ & 2-4 cm chip & $\begin{array}{l}60 \% \mathrm{Na}, 45 \% \mathrm{~K}, 18 \% \mathrm{Mg}, 4 \% \mathrm{Ca}, 27 \% \mathrm{PO}_{4}{ }^{3-}, 8 \% \\
\mathrm{SO}_{4}^{2-} \text {, up to } 100 \% \mathrm{Cl}\end{array}$ & [30] \\
\hline Miscanthus & $\begin{array}{l}\mathrm{Na}, \quad \mathrm{K}, \quad \mathrm{Ca} \\
\mathrm{Mg}, \mathrm{P}, \mathrm{S}, \mathrm{Cl}\end{array}$ & Water & $\begin{array}{l}\text { Room temp, } \\
\text { 20h stirred }\end{array}$ & $\begin{array}{l}1-3 \quad \mathrm{~cm} \\
\text { chopped }\end{array}$ & $\begin{array}{l}53 \% \mathrm{Na}, 62 \% \mathrm{~K}, 56 \% \mathrm{Mg}, 19 \% \mathrm{Ca}, 49 \% \mathrm{PO}_{4}{ }^{3-}, 33 \% \\
\mathrm{SO}_{4}^{2-}, 84 \% \mathrm{Cl}\end{array}$ & [30] \\
\hline Wheat straw & $\begin{array}{l}\mathrm{Na}, \quad \mathrm{K}, \quad \mathrm{Ca} \\
\mathrm{Mg}, \mathrm{P}, \mathrm{S}, \mathrm{Cl}\end{array}$ & Water & $\begin{array}{l}\text { Room temp, } \\
\text { 20h stirred }\end{array}$ & $\begin{array}{l}1-3 \quad \mathrm{~cm} \\
\text { chopped }\end{array}$ & $\begin{array}{l}92 \% \mathrm{Na}, 54 \% \mathrm{~K}, 32 \% \mathrm{Mg}, 12 \% \mathrm{Ca}, 0.2 \% \mathrm{PO}_{4}{ }^{3-}, 21 \% \\
\mathrm{SO}_{4}^{2-}, 100 \% \mathrm{Cl}\end{array}$ & [30] \\
\hline Peach Stones & $\begin{array}{l}\mathrm{K}, \mathrm{Na}, \mathrm{Cl}, \mathrm{Mg}, \\
\mathrm{Fe}\end{array}$ & Water & $\begin{array}{l}20^{\circ} \mathrm{C}, \quad 8 \mathrm{~h}, \\
\text { soaked }\end{array}$ & $?$ & $70 \% \mathrm{Cl}, 30 \% \mathrm{~K}, 40 \% \mathrm{Na}, 50 \% \mathrm{Ca}, 70 \% \mathrm{Mg}, 30 \% \mathrm{Fe}$ & [41] \\
\hline $\begin{array}{l}\text { Wood, forest residue, } \\
\text { bark, waste wood }\end{array}$ & $\begin{array}{l}\mathrm{Si}, \mathrm{Al}, \mathrm{Fe}, \mathrm{Ca}, \\
\mathrm{Mg}, \mathrm{Na}, \mathrm{K}, \mathrm{P}, \\
\mathrm{S}\end{array}$ & Water & $\begin{array}{l}\text { Room temp, } \\
\text { soaked }\end{array}$ & $<5 \mathrm{~mm}$ & $\begin{array}{l}<10 \% \mathrm{Si}, 4-15 \% \mathrm{Al}, \sim 5 \% \mathrm{Fe}, 5-15 \% \mathrm{Ca}, 15-20 \% \mathrm{Mg} \\
35-45 \% \mathrm{Na}, 50-65 \% \mathrm{~K}, 25-50 \% \mathrm{P}, 10-30 \% \mathrm{~S} .\end{array}$ & [17] \\
\hline Straw & $\begin{array}{l}\mathrm{Si}, \mathrm{Al}, \mathrm{Fe}, \mathrm{Ca} \\
\mathrm{Mg}, \mathrm{Na}, \mathrm{K}, \mathrm{P}\end{array}$ & Water & $\begin{array}{l}\text { Room temp, } \\
\text { soaked }\end{array}$ & $<5 \mathrm{~mm}$ & $\begin{array}{l}\sim 5 \% \mathrm{Si}, \sim 5 \% \mathrm{Al}, \sim 5 \% \mathrm{Fe}, \sim 25 \% \mathrm{Ca}, \sim 40 \% \mathrm{Mg}, \\
\sim 60 \% \mathrm{Na}, \sim 80 \% \mathrm{~K}, \sim 65 \% \mathrm{P}, \sim 60 \% \mathrm{~S}\end{array}$ & [17] \\
\hline
\end{tabular}




\begin{tabular}{|c|c|c|c|c|c|c|}
\hline & $\mathrm{S}$ & & & & & \\
\hline $\begin{array}{l}\text { Spruce, Pine, Birch, } \\
\text { Aspen (stem, bark, } \\
\text { twigs, branch woods) }\end{array}$ & $\begin{array}{l}\mathrm{K}, \mathrm{Na}, \mathrm{Mg}, \\
\mathrm{Mn}, \quad \mathrm{Ca}, \quad \mathrm{Al}, \\
\mathrm{Fe}, \mathrm{Cl}, \mathrm{P}, \mathrm{S}, \mathrm{Si}\end{array}$ & Water & $\begin{array}{l}\text { Room temp. } \\
24 \mathrm{~h} \text { stirred }\end{array}$ & $<1 \mathrm{~mm}$ & $\begin{array}{l}75 \% \mathrm{~K}, 65 \% \mathrm{Na}, 40 \% \mathrm{Mg}, 25 \% \mathrm{Mn} \text { (bark, twigs, } \\
\text { foliage all species), } 25 \% \mathrm{Ca} \text { (stem wood), } 10 \% \mathrm{Al} \\
\text { (spruce, birch, aspen), } 5 \% \mathrm{Fe}, 90 \% \mathrm{Cl}, 65 \% \mathrm{P}, 15 \% \mathrm{~S} \text {, } \\
5 \% \mathrm{Si}\end{array}$ & [31] \\
\hline Wheat straw & $\begin{array}{l}\text { Al, } \mathrm{Si}, \mathrm{Ti}, \mathrm{Fe}, \\
\mathrm{Ca}, \mathrm{Mg}, \mathrm{Na}, \\
\mathrm{K}, \mathrm{S}, \mathrm{P}, \mathrm{Cl}\end{array}$ & Water & $\begin{array}{l}30, \quad 60, \\
90^{\circ} \mathrm{C}, 3 \mathrm{~h}\end{array}$ & $280-450 \mu \mathrm{m}$ & $\begin{array}{l}\text { Ash removal increases with temperature of the water } \\
\text { (from } 55-75 \% \text { reduction). } \mathrm{SiO} 2 \text { removal efficiency } \\
\text { increases with water temperature }(25-65 \%) \text {. A small } \\
\text { benefit for } \mathrm{K} \text { removal with } \mathrm{T} \text {, but }>90 \% \text { removed at } \\
\text { all temps. } \mathrm{S} 85-95 \% \text { removed, } \mathrm{Cl} 70-85 \% \text { removed }\end{array}$ & [32] \\
\hline Rice straw & $\begin{array}{l}\mathrm{Al}, \mathrm{Si}, \mathrm{Ti}, \mathrm{Fe}, \\
\mathrm{Ca}, \mathrm{Mg}, \mathrm{Na}, \\
\mathrm{K}, \mathrm{S}, \mathrm{P}, \mathrm{Cl}\end{array}$ & Water & $\begin{array}{l}30,60,90^{\circ} \mathrm{C} \\
3 \mathrm{~h}\end{array}$ & $280-450 \mu \mathrm{m}$ & $\begin{array}{l}\text { Ash removal increases with temperature of the water } \\
\text { (from } 20-40 \% \text { reduction). SiO2 removal efficiency } \\
\text { increases with water temperature }(2-30 \%) \text {. A small } \\
\text { benefit for K removal with } \mathrm{T} \text {, but }>86 \% \text { removed at } \\
\text { all temps. S } 90-95 \% \text { removed, } \mathrm{Cl}>90 \% \text { removed at } \\
\text { all temps. }\end{array}$ & [32] \\
\hline Corn stalk & $\begin{array}{l}\mathrm{Al}, \mathrm{Si}, \mathrm{Ti}, \mathrm{Fe}, \\
\mathrm{Ca}, \mathrm{Mg}, \mathrm{Na}, \\
\mathrm{K}, \mathrm{S}, \mathrm{P}, \mathrm{Cl}\end{array}$ & Water & $\begin{array}{l}30,60,90^{\circ} \mathrm{C} \\
3 \mathrm{~h}\end{array}$ & $280-450 \mu \mathrm{m}$ & $\begin{array}{l}\text { Ash removal increases with temperature of the water } \\
\text { (from } 60-70 \% \text { reduction). SiO2 removal efficiency } \\
\text { increases with water temperature }(65-75 \% \text { ). A benefit } \\
\text { is seen for } \mathrm{K} \text { removal with } \mathrm{T} \text {, but }>85 \% \text { removed at } \\
\text { all temps. Small benefit of water } \mathrm{T} \text { for } \mathrm{S} \text { : }>90 \% \\
\text { removed, } \mathrm{Cl} 35-58 \% \text { removed and a negative effect of } \\
\mathrm{T} \text { seen. }\end{array}$ & [32] \\
\hline Cotton stalk & $\begin{array}{l}\mathrm{Al}, \mathrm{Si}, \mathrm{Ti}, \mathrm{Fe}, \\
\mathrm{Ca}, \mathrm{Mg}, \mathrm{Na}, \\
\mathrm{K}, \mathrm{S}, \mathrm{P}, \mathrm{Cl}\end{array}$ & Water & $\begin{array}{l}30,60,90^{\circ} \mathrm{C} \\
3 \mathrm{~h}\end{array}$ & $280-450 \mu \mathrm{m}$ & $\begin{array}{l}\text { Ash removal increases with temperature of the water } \\
\text { (from } 20-40 \% \text { reduction). } \mathrm{SiO} 2 \text { removal efficiency } \\
\text { increases with water temperature }(2-30 \%) \text {. A small } \\
\text { benefit for K removal with } \mathrm{T} \text {, but }>86 \% \text { removed at } \\
\text { all temps. S } 90-95 \% \text { removed, } \mathrm{Cl} \text { also showed a } \\
\text { benefit for hot water } 85-95 \% \text { removed. }\end{array}$ & [32] \\
\hline Candlenut wood & $\begin{array}{l}\text { Al, } \mathrm{Si}, \mathrm{Ti}, \mathrm{Fe}, \\
\mathrm{Ca}, \mathrm{Mg}, \mathrm{Na}, \\
\mathrm{K}, \mathrm{S}, \mathrm{P}, \mathrm{Cl}\end{array}$ & Water & $\begin{array}{l}30,60,90^{\circ} \mathrm{C} \\
3 \mathrm{~h}\end{array}$ & $280-450 \mu \mathrm{m}$ & $\begin{array}{l}\text { Ash removal increases with temperature of the water } \\
\text { (from } 10-30 \% \text { reduction). SiO2 removal efficiency } \\
\text { increases with water temperature }(10-30 \%) \text {. A large } \\
\text { benefit for } \mathrm{K} \text { removal with } \mathrm{T} \text { from } 70-85 \% \text { removal. S } \\
75 \% \text { removed at all temps. Small benefit from hot } \\
\text { water for } \mathrm{Cl} 50-55 \% \text { removed. }\end{array}$ & [32] \\
\hline
\end{tabular}




\begin{tabular}{|c|c|c|c|c|c|c|}
\hline Rice Hull & $\begin{array}{l}\mathrm{Al}, \mathrm{Si}, \mathrm{Ti}, \mathrm{Fe} \\
\mathrm{Ca}, \mathrm{Mg}, \mathrm{Na} \\
\mathrm{K}, \mathrm{S}, \mathrm{P}, \mathrm{Cl}\end{array}$ & Water & $\begin{array}{l}30,60,90^{\circ} \mathrm{C} \\
3 \mathrm{~h}\end{array}$ & $280-450 \mu \mathrm{m}$ & $\begin{array}{l}\text { Ash removal slightly increases with temperature of } \\
\text { the water (from } 5-10 \% \text { reduction). } \mathrm{SiO} 2 \text { removal } \\
\text { efficiency slightly increases with water temperature } \\
(5-10 \%) \text {. A benefit is seen for } \mathrm{K} \text { removal with } \mathrm{T} \text {, } \\
\text { from } 85 \% \text { to }>90 \% \text {. } \mathrm{S} 60-80 \% \text { removed, } \mathrm{Cl} 68-85 \% \\
\text { removed, } 60^{\circ} \mathrm{C} \text { was best. }\end{array}$ & [32] \\
\hline Rice straw, & $\begin{array}{l}\mathrm{Al}, \mathrm{Si}, \mathrm{Ti}, \mathrm{Fe} \\
\mathrm{Ca}, \mathrm{Mg}, \mathrm{Na}, \\
\mathrm{K}, \mathrm{S}, \mathrm{P}, \mathrm{Cl}\end{array}$ & Water & $\begin{array}{l}20-25^{\circ} \mathrm{C} \\
\text { spray, } \\
\text { pouring, } \\
\text { soaking } 24 \mathrm{~h}\end{array}$ & $<90 \mathrm{~mm}$ & $\begin{array}{l}\text { Spraying: All species except } \mathrm{Si}, \mathrm{Ti}, \mathrm{Ca}, \mathrm{Mg} \text { decreased } \\
\text { significantly: } \mathrm{Cl} 50 \% \text { reduction, } \mathrm{Na} 20 \% \text { reduction, K } \\
\text { and P } 40 \% \text { reductions, } \mathrm{S} 10 \% \text { reduction. } \\
\text { Soaking: All species except } \mathrm{Si}, \mathrm{Ti}, \mathrm{Ca} \text { decreased } \\
\text { significantly: } \mathrm{Cl} 90 \%, \mathrm{Mg} 55 \%, \mathrm{Na} 90 \%, \mathrm{~K} 80 \%, \mathrm{P} \\
80 \%, \mathrm{~S} 70 \% \\
\text { Rain washed: All species decrease except } \mathrm{Si}, \mathrm{Ti}, \mathrm{Ca} \text {. } \\
\text { Similar results to soaking observed. }\end{array}$ & [27] \\
\hline wheat straw & $\begin{array}{l}\text { Al, } \mathrm{Si}, \mathrm{Ti}, \mathrm{Fe} \\
\mathrm{Ca}, \mathrm{Mg}, \mathrm{Na} \\
\mathrm{K}, \mathrm{S}, \mathrm{P}, \mathrm{Cl}\end{array}$ & Water & $\begin{array}{l}20-25^{\circ} \mathrm{C} \\
\text { spray, } \\
\text { pouring, } \\
\text { soaking } 24 \mathrm{~h}\end{array}$ & $<90 \mathrm{~mm}$ & $\begin{array}{l}\text { Soaking results reported. Greater than } 80 \% \text { removal } \\
\text { of } \mathrm{Cl}, \mathrm{Na}, \mathrm{K} \text { and } \mathrm{S} .37 \% \text { and } 53 \% \text { removal of } \mathrm{Ca} \text { and } \\
\mathrm{Mg} \text { respectively, }\end{array}$ & [27] \\
\hline $\begin{array}{l}\text { Eucalyptus } \\
\text { Loxophleba (mallee) }\end{array}$ & $\begin{array}{l}\mathrm{Na}, \quad \mathrm{K}, \quad \mathrm{Mg}, \\
\mathrm{Ca}, \mathrm{Cl}\end{array}$ & Water & $\begin{array}{l}\text { Room } \\
\text { Temp. } \\
\text { Sampled } \\
\text { with time }\end{array}$ & $150-250 \mu \mathrm{m}$ & $\begin{array}{l}\mathrm{Na}, \mathrm{K}, 80-95 \% \text { removal; } \mathrm{Cl} 100 \% \text { removal; } \mathrm{Mg}, \mathrm{Ca} \\
10-30 \% \text { removal. Differences seen between batch and } \\
\text { semi-continuous operation. }\end{array}$ & [33] \\
\hline Type C Red Pine & $\mathrm{As}, \mathrm{Cr}, \mathrm{Cu}$ & $\begin{array}{l}0.19 \mathrm{~N} \\
\mathrm{H}_{2} \mathrm{SO}_{4}\end{array}$ & $\begin{array}{l}75^{\circ} \mathrm{C} \\
\text { soaked }\end{array}$ & $<12 \mathrm{~mm}$ & $\begin{array}{l}1^{\text {st }} \text { leaching step: } 71 \pm 19 \% \text { As, } 69 \pm 21 \% \mathrm{Cr}, 77 \pm 15 \% \\
\mathrm{Cu} \\
2^{\text {nd }} \text { leaching step: } 92 \pm+6 \% \mathrm{As}, 87 \pm 9 \% \mathrm{Cr}, 94 \pm 5 \% \mathrm{Cu} \\
3^{\text {rd }} \text { leaching step: } 98 \pm+1 \% \mathrm{As}, 94 \pm 4 \% \mathrm{Cr}, 99 \pm 1 \% \mathrm{Cu}\end{array}$ & [40] \\
\hline $\begin{array}{lll}\text { Empty } & \text { Fruit } & \text { Bunch } \\
\text { (EFB) } & & \end{array}$ & $\begin{array}{l}\mathrm{K}, \mathrm{Ca}, \mathrm{Mg}, \mathrm{Fe}, \\
\mathrm{Al} \text { and } \mathrm{Na}\end{array}$ & Water & $\begin{array}{l}25,40 \text { and } \\
55^{\circ} \mathrm{C} \text { for } 1 \\
3,5,10,30\end{array}$ & $0.31 \mathrm{~mm}$ & $\begin{array}{l}50 \% \text { ash removal at } 5 \text { minutes at } 25^{\circ} \mathrm{C} \text {. No effect on } \\
\text { ash removal of different temperatures. } \\
71 \%, 52 \% \text { and } 23 \% \text { removal of } \mathrm{K}, \mathrm{Ca} \text { and } \mathrm{Mg}\end{array}$ & [42] \\
\hline
\end{tabular}




\begin{tabular}{|c|c|c|c|c|c|c|}
\hline & & & $\begin{array}{l}60 \text { and } 120 \\
\text { mins, stirred }\end{array}$ & & $\begin{array}{l}\text { respectively at } 25^{\circ} \mathrm{C} \\
85 \%, 71 \% \text { and } 41 \% \text { removal of } \mathrm{K}, \mathrm{Ca} \text { and } \mathrm{Mg} \\
\text { respectively at } 25^{\circ} \mathrm{C} \\
\mathrm{Al}, \mathrm{Fe} \text { and } \mathrm{Na} \text { present in negligible amounts }\end{array}$ & \\
\hline $\begin{array}{lll}\text { Palm } & \text { Kernel } & \text { Shell } \\
\text { (PKS) } & & \end{array}$ & $\begin{array}{l}\mathrm{K}, \mathrm{Ca}, \mathrm{Mg}, \mathrm{Fe} \text {, } \\
\mathrm{Al} \text { and } \mathrm{Na}\end{array}$ & Water & $\begin{array}{l}25,40 \text { and } \\
55^{\circ} \mathrm{C} \text { for } 1, \\
3,5,10,30, \\
60 \text { and } 120 \\
\text { mins, stirred }\end{array}$ & $0.72 \mathrm{~mm}$ & $\begin{array}{l}25 \% \text { ash removal at } 1 \text { minute at } 25^{\circ} \mathrm{C} \text {.No further } \\
\text { removal of ash with time. } \\
\text { Similar trends for metals' leaching as those for EFB }\end{array}$ & [42] \\
\hline Sorghum & $\begin{array}{l}\text { Total halogens } \\
(\mathrm{Cl}, \mathrm{Br} \text { and } \mathrm{I}) \\
\mathrm{Cl} \text {, }\end{array}$ & Water & $\begin{array}{l}7.6 \mathrm{~L} \text { (single) } \\
15.2 \mathrm{~L} \\
\text { (double) and } \\
22.8 \mathrm{~L} \\
\text { (triple) } \\
\text { wash, } \\
7.6 \mathrm{~L} \text { soak }\end{array}$ & $<8 \mathrm{~mm}$ & $\begin{array}{l}14 \% \text { ash removal with single pour and } 20 \% \text { ash } \\
\text { removal with triple wash. } \\
73 \% \text { removal of total halogens } \\
57-73 \% \text { removal of soluble chlorine. }\end{array}$ & [43] \\
\hline Sorghum & $\mathrm{K} . \mathrm{Ca}$ and $\mathrm{Mg}$ & Water & $\begin{array}{l}\text { 7.6L (single) } \\
15.2 \mathrm{~L} \\
\text { (double) and } \\
22.8 \mathrm{~L} \\
\text { (triple) } \\
\text { washing, } \\
\text { 7.6L soak }\end{array}$ & $<8 \mathrm{~mm}$ & $\begin{array}{l}\text { Single wash: } 42 \% \mathrm{~K}, 15 \% \mathrm{Mg} \text { and } 14 \% \mathrm{Ca} \\
\text { Double wash: } 56 \% \mathrm{~K}, 24 \% \mathrm{Mg} \text { and } 19 \% \mathrm{Ca} \\
\text { Triple wash: } 62 \% \mathrm{~K}, 27 \% \mathrm{Mg} \text { and } 20 \% \mathrm{Ca} \\
\text { Soak52\% K, } 25 \% \mathrm{Mg} \text { and } 25 \% \mathrm{Ca}\end{array}$ & [43] \\
\hline
\end{tabular}




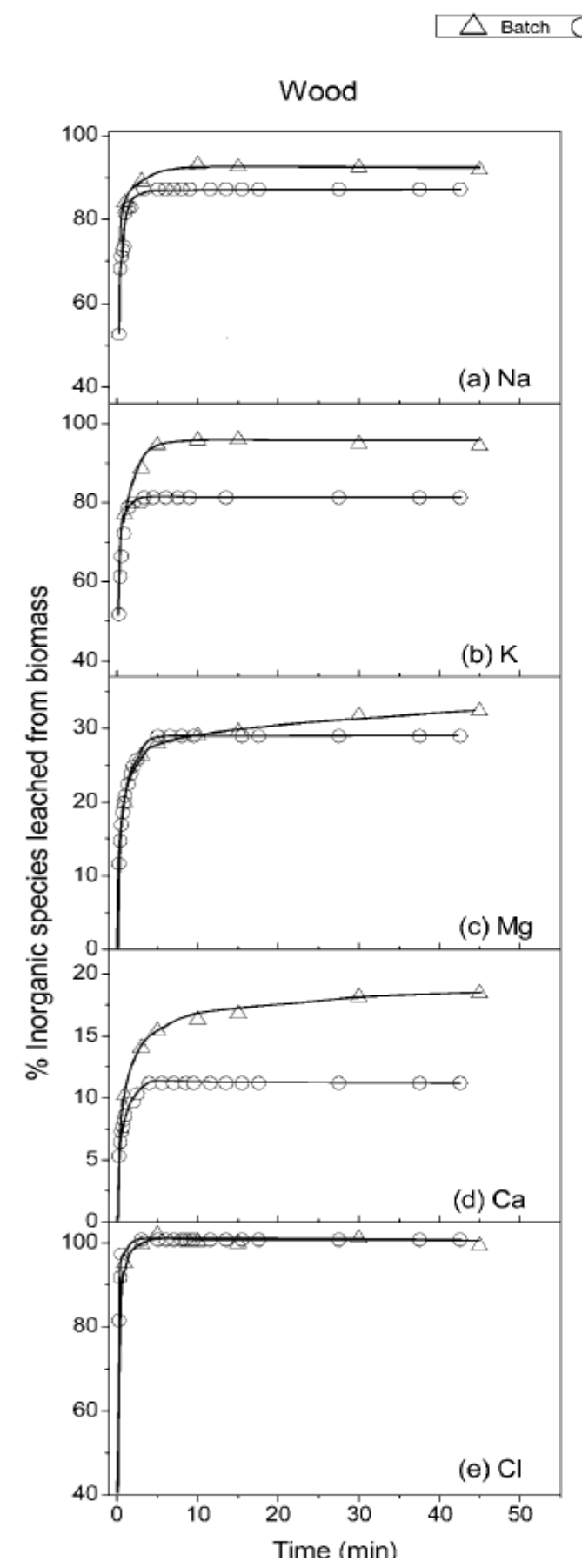

Semi-continuous

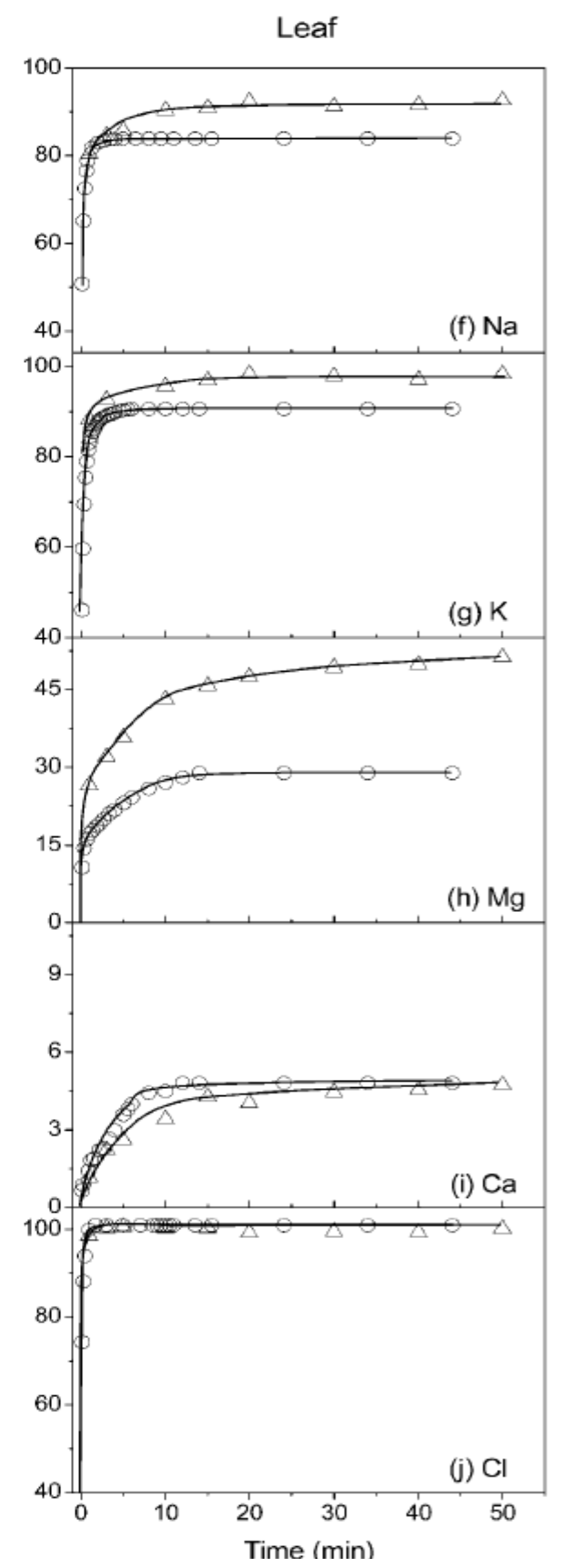

Fig 4 Percentage of various inorganic species leached from the water washing of mallee wood and leaf as a function of leaching time in batch and semi-continuous systems.

(Reprinted with permission from Liaw, S.B. and Wu, H., Leaching Characteristics of Organic and Inorganic Matter from Biomass by Water: Differences between Batch and Semi-continuous Operations. Industrial \& Engineering Chemistry Research, 2013. 52(11): p. 4280-4289.Copyright 2013. American Chemical Society 
Washing of biomass also results in extraction of organic material, particularly organic acids (acetic, formic), oxalate [33] and some sugars, lipids, tannins and essential oils [44]. Second order kinetics have been successfully applied to the leaching of organics from Tilia sapwood (as measured by mass of dry matter):

$$
\frac{d C_{t}}{d t}=k\left(C_{s}-C_{t}\right)^{2}
$$

$$
\text { Where: } \quad k=65.5 e^{-21.9 / R T}
$$

Unpublished work from our laboratory has also suggested that elevated temperature enhances extraction of organics. Extraction of organics can have a small effect on the heating value, especially from high lipid biomass [30]. The impact of emissions of Volatile Organic Compounds (VOC) or other organics and soot during combustion as a result of washing has not been investigated.

\subsection{Potential impact on ash behaviour and emissions.}

As described earlier, the alkali metals, potassium in particular, are very volatile and during combustion enter the vapour phase as alkali chlorides or hydroxides. These undergo transformation into sulphates and lead to fouling in convective boiler regions because it reduces the ash fusion temperature. During combustion, potassium is released both during volatile and char combustion stages. Jones et al [45] used thermogravimetric analysis to investigate the char combustion peak temperatures for a number of treated willow samples. They increased with decreasing potassium contents indicating that potassium acts as a catalyst during combustion.

Davidsson et al. [46] also studied the release of $\mathrm{K}$ from two wheat straws and a wood waste (mainly pine and birch) after various pre-treatments. They washed with water at 20$25^{\circ} \mathrm{C}$, as well as acid washing at room temperature. After pre-treatment, samples were heated in $\mathrm{N}_{2}$ to $1000^{\circ} \mathrm{C}$ and evolution of $\mathrm{K}$ from detected via a surface ionisation detector. Water washing reduced the alkali emission in the $200-500^{\circ} \mathrm{C}$ region (pyrolysis) by $5-30 \%$, and for emission from the region above $600^{\circ} \mathrm{C}$ (vapourisation of alkali salts) by $90 \%$. Similar results were observed for both wheat straw and waste woods. Thus decreasing the concentration of alkali metal in the biomass fuels decreases in its fouling propensity. From the results reported by Jenkins et al [27] it is possible to calculate the expected fouling behaviour of rice and wheat straw after exposure to the different washing approaches. For the " $65 \mathrm{~mm}$ rain washed sample", the sample was exposed to a total of $65 \mathrm{~mm}$ of rain over 3 days before it was collected from the field. This data is shown in Figure 5 (a). Fouling behaviour is also calculated from data reported by Miles et al and concerning washing of rice straw, wheat straw, alfalfa stems and rice hulls and is reported in Fig 5 (b). Soaking approaches result in fuels which are no longer certain to cause fouling. 


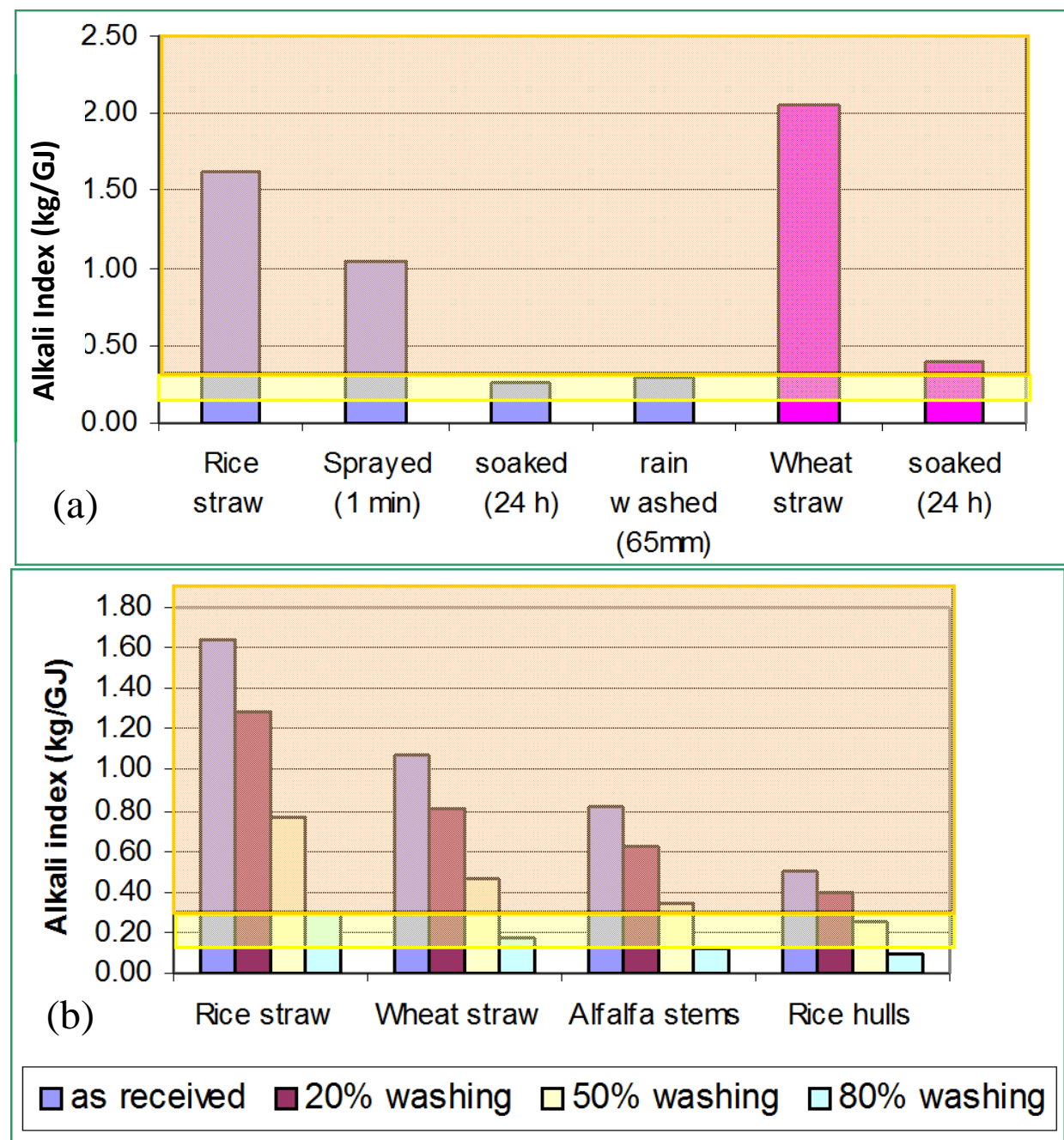

Fig 5 Influence of washing pre-treatment on the alkali index of rice straw and wheat straw. Pink shaded area indicates fouling almost certain, yellow shaded area indicates fouling probable to occur $[27,29]$.

Data from [27] can be used to examine the influence of pre-treatment on both the base/acid ratio and the Fouling Index as given in Equations (1) and (5) respectively. Results are given in Figure 6 (a) and 6 (b). Based on the $R_{b / a}$, washing is predicted to improve (decrease) the slagging behaviour of both fuels, but particularly wheat straw, as shown in Fig 6 (a). A rule of thumb is severe slagging for $R_{b / a}$ 0.4-0.6 as shown by the red shaded band. Similar benefits are predicted based on the fouling index for rice straw (Fig 6 (b)). Washing of both fuels results in fuels which are predicted to have very much improved ash behaviour.

Several workers have also examined the impact of different washing pre-treatments on ash fusion temperatures. Our own data [30] showed a significant increase in characteristic ash fusion temperatures after water washing. For example, the hemisphere temperature increased by 400 and $290^{\circ} \mathrm{C}$ for wheat straw and Miscanthus respectively. 

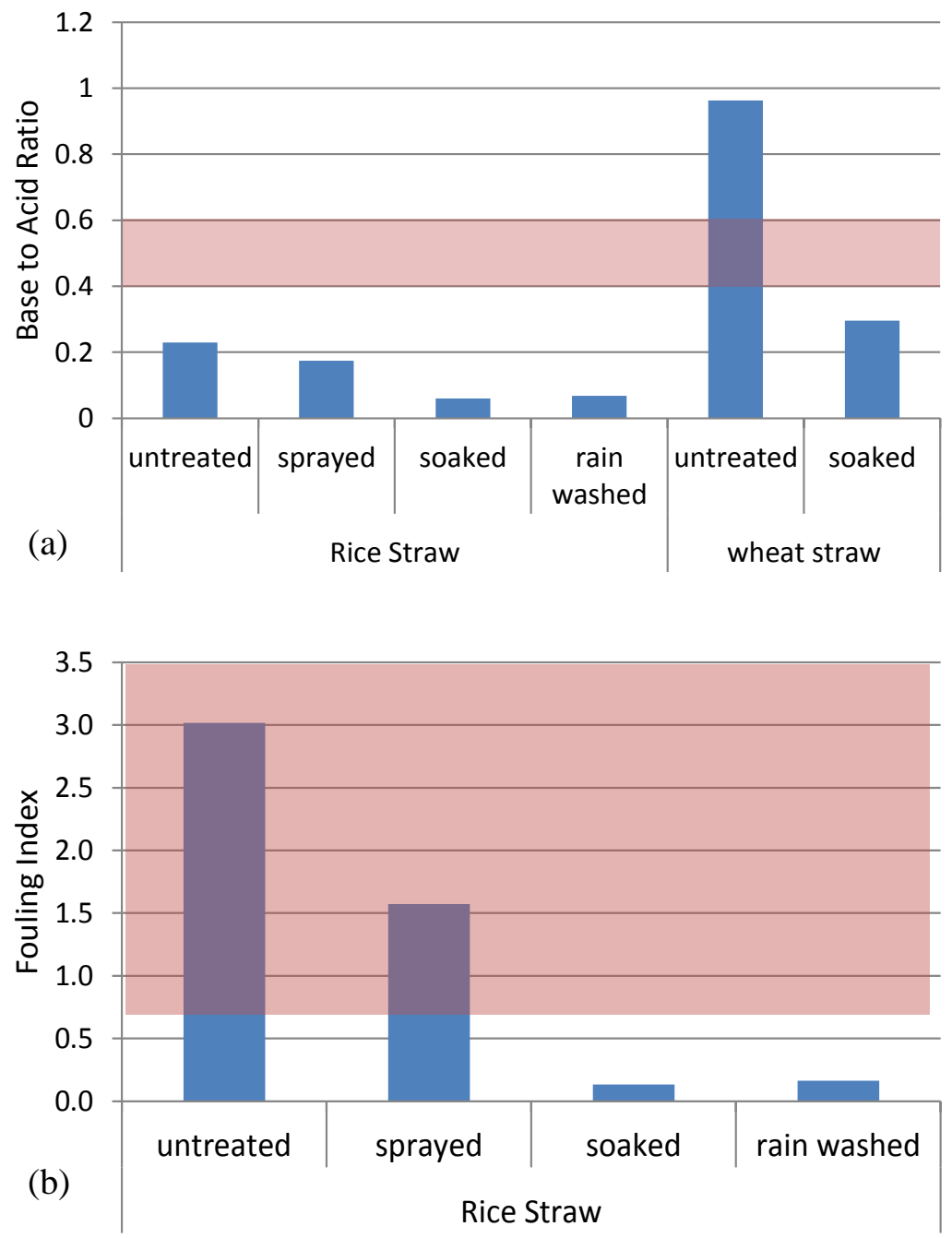

Fig 6 (a) Base to acid ratio of untreated and pre-treated rice straw and wheat straw. Red shaded region shows typical $\mathrm{R}_{\mathrm{b} / \mathrm{a}}$ for low melting ashes. (b) Fouling index of untreated and pre-treated rice straw. Red shaded regions show high fouling risk [27]

EPRI (Electric Power Research Institute) in the States has published recent information concerning their programme in pre-treatment technologies. Fig 7 shows ash melting temperatures of a variety of fuels after pre-treatment. Note that this study includes waste woods, and the ash melting temperature increased from $\sim 850^{\circ} \mathrm{C}$ to $1400^{\circ} \mathrm{C}$ after pretreatment. Similar increases are observed for all fuels. 


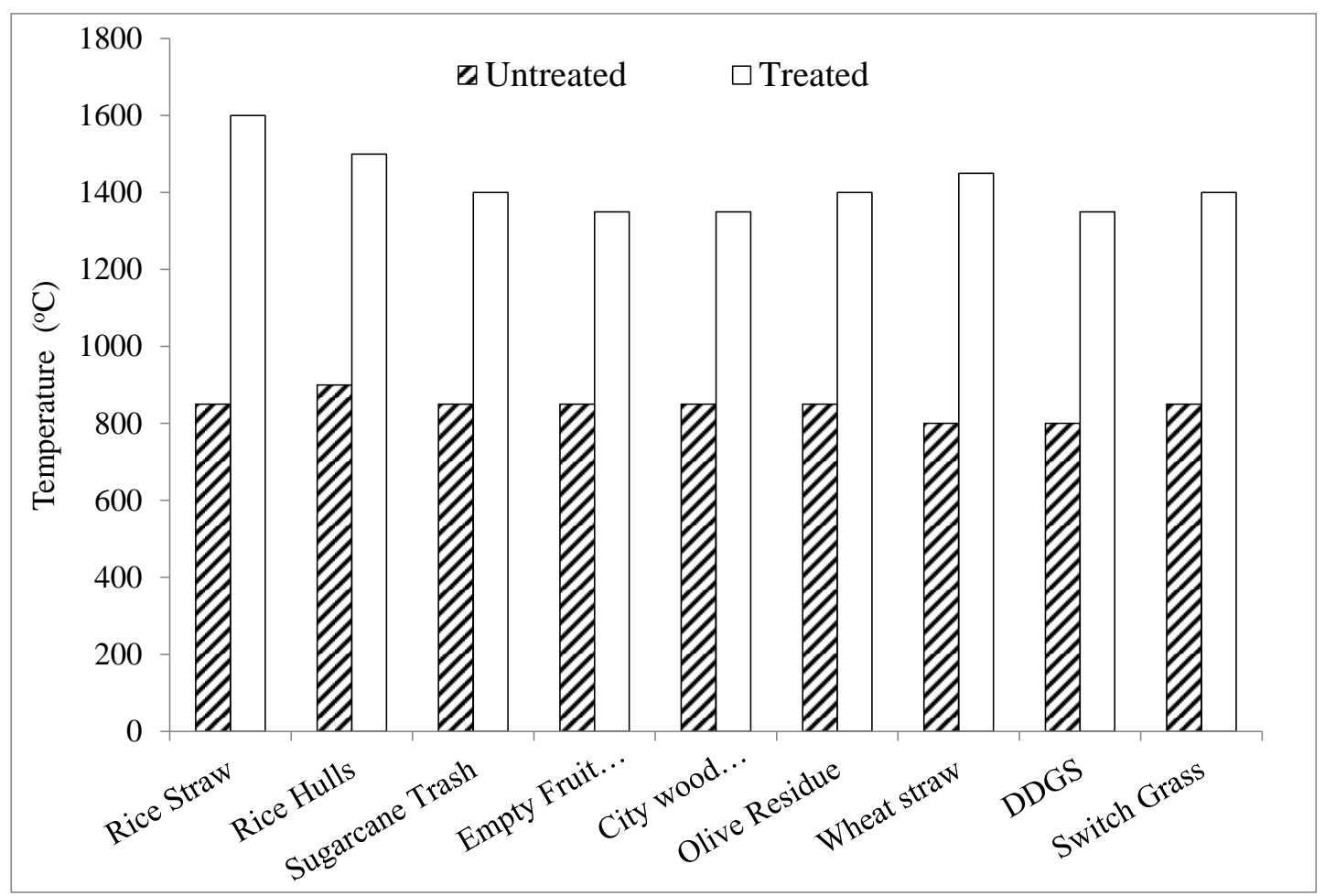

Fig 7 Influence of pre-treatments on the ash melting temperatures of various biomass [47]

In general, large quantities of water are required for washing biomass in order to improve the fuel quality but the disposal of the contaminated water is a problem since it needs to be treated before it can be disposed off into streams or rivers. This increases costs. Hot water washing is a better option since the high temperatures aid in the removal of the impurities from the biomass hence reducing the amount of water required for washing. Potentially in power stations, the effluent from the process can be used to wash the biomass since it is already at high temperatures.

The issues relating to category $\mathrm{B}$ and $\mathrm{C}$ of waste woods have not been reviewed. Significant leaching of CCA is expected and water remediation would need to be considered in this case. Warm water washing is also expected to enhance extraction of organic components, affecting the $\mathrm{COD}, \mathrm{BOD}$ and $\mathrm{pH}$ of the leachate

\section{Conclusions}

A literature review based on laboratory scale studies has been undertaken and the following conclusions were made:

1. Washing with water at ambient temperature reduces the ash content of the fuel.

2. The efficiencies of removal decreases as particle size increases, and increases as the temperature of the washing water increases.

3. Hot washing of waste wood has been shown to increase ash melting temperatures from around $820^{\circ} \mathrm{C}$ at worst through to ca. $1400^{\circ} \mathrm{C}$ at best.

4. Hot washing of waste wood has been shown to reduce concentrations of chlorine $(\mathrm{Cl})$ by $30-100 \%$, potassium $(\mathrm{K})$ by $50-90 \%$, sodium $(\mathrm{Na})$ by $10-90 \%$ (typically 
$40 \% \mathrm{~min}$ ), calcium (Ca) by 5-35\%, magnesium $(\mathrm{Mg})$ by $5-60 \%$, sulphur (S) by $0-$ $95 \%\{$ lower end in wood $\}$, phosphorous $(\mathrm{P})$ by $10-80 \%$, and iron $(\mathrm{Fe})$ by $0-30 \%$.

5. Silicon ( $\mathrm{Si})$, titanium (Ti), and aluminium (Al) are far less soluble; some small reductions have been observed using cold water washing for these elements however (up to 15\%). Studies on $\mathrm{SiO} 2$ suggest improved solubility with hot water. However, this technique will have limited use to mitigate the impacts of these elements in feedstock.

6. The impact of washing is minimal on High Heating Value (HHV). However ash content tends to reduce significantly, hence reducing the tendency of fouling and slagging to occur in boilers and furnaces.

7. Reduction in $\mathrm{Cl}$ and $\mathrm{S}$ contents significantly affects formation of acid gases and consequently acid corrosion on boiler components and associated environmental impacts.

\section{Acknowledgements}

We acknowledge financial support from The University of Leeds, EPSRC Impact Acceleration Account (IAA) and Energy Leeds. We also wish to thank George Stammers (Innovation Manager, Veolia) for the review discussion.

\section{References}

1. Government, H., The UK Renewable Energy Stratergy. 2009.

2. "British Standard CEN/TS 14961: 2005 Solid biofuels — Fuel specifications and classes. 2005.

3. Fuel specifications and classes. Wood pellets for non-industrial use BS EN 14961-2. Solid Biofuels, 2011.

4. Darvell, L.I., Jones, J.M., Gudka, B., Baxter, X.C., Saddawi, A., Williams, A. and Malmgren, A., Combustion properties of some power station biomass fuels. Fuel, 2010. 89(10): p. 2881-2890.

5. .Gudka, B., Jones, J.M., Mohammed, A., Norfolk, J., Barraclough, T., Riche, A.B., Shield, I. and Yates, N.E., Combustion Characteristics and Combustion Related Problems for Short Rotation Coppice (SRC) Willow. in 18th European Biomass Congress and Exhibition, 3-7 May, 2010.

6. Baxter, X.C., Darvell, L.I., Jones, J.M., Barraclough, T., Yates, N.E. and Shield, I., Study of Miscanthus $\mathrm{x}$ giganteus ash composition - Variation with agronomy and assessment method. Fuel, 2012. 95(0): p. 50-62.

7. Christian, D.G., Riche, A.B. and Yates, N.E., The yield and composition of switchgrass and coastal panic grass grown as a biofuel in Southern England. Bioresource Technology, 2002. 83(2): p. 115-124.

8. Christian, D.G., Yates, N.E. and Riche, A.B., The effect of harvest date on the yield and mineral content of Phalaris arundinacea L. (reed canary grass) genotypes screened for their potential as energy crops in southern England. Journal of the Science of Food and Agriculture, 2006. 86(8): p. 1181-1188. 
9. Clifton-Brown, J.C., Lewandowski, I., Andersson, B., Basch, G., Christian, D.G., Kjeldsen, J.B., Jørgensen, U., Mortensen, J.V., Riche, A.B., Schwarz, K.-U., Tayebi, K. and Teixeira, F., Performance of 15 Miscanthus Genotypes at Five Sites in Europe Current address of J.C. Clifton-Brown: Bot. Dep., Univ. of Dublin, Trinity College, Dublin 2, Ireland. This work was funded by the EU Contract no. FAIR3 CT-96-1392. Agron. J., 2001. 93(5): p. 1013-1019.

10. Darvell, L.I., Jones, J.M., Shield, I., Riche, A.B., Yates, N.E. and Barraclough, T., The influence of agronomic treatment on the combustion characteristics of some energy crops,. Aspects of Applied Biology, 2008: p. 91.

11. Bridgeman, T.G., Jones, J.M. and Williams, A., Overview of Solid Fuels, Characteristics and Origin, in Handbook of Combustion. 2010, Wiley-VCH Verlag GmbH \& Co. KGaA.

12. Bryers, R.W., Fireside slagging, fouling, and high-temperature corrosion of heat-transfer surface due to impurities in steam-raising fuels. Progress in Energy and Combustion Science, 1996. 22(1): p. 29-120.

13. Jenkins, B.M., Baxter, L.L. and Miles, T.R., Combustion properties of biomass. Fuel Processing Technology, 1998. 54(1-3): p. 17-46.

14. Miles, T.R., Miles Jr, T.R., Baxter, L.L., Bryers, R.W., Jenkins, B.M. and Oden, L.L., Boiler deposits from firing biomass fuels. Biomass and Bioenergy, 1996. 10(2-3): p. 125138.

15. Van Loo, S., Koppejan, J. and Eds, Hamdbook of Biomass Combustion and Co-firing. Earthscan Publishers, 2010.

16. Baxter, X.C., Combustion Properties of Miscanthus: Impact of Ash and Agronomy. 2011: University of Leeds (School of Process, Environmental and Materials Engineering).

17. Zevenhoven, M., Yrjas, P., Skrifvars, B.-J. and Hupa, M., Characterization of AshForming Matter in Various Solid Fuels by Selective Leaching and Its Implications for Fluidized-Bed Combustion. Energy \& Fuels, 2012. 26(10): p. 6366-6386.

18. British Standards, Fly ash for concrete. Definition, specifications and conformity criteria, BS-EN450-1-2012, 2012.

19. Glarborg, P. and Marshall, P., Mechanism and modeling of the formation of gaseous alkali sulfates. Combustion and Flame, 2005. 141(1-2): p. 22-39.

20. Westberg, H.M., Byström, M. and Leckner, B., Distribution of Potassium, Chlorine, and Sulfur between Solid and Vapor Phases during Combustion of Wood Chips and Coal. Energy \& Fuels, 2002. 17(1): p. 18-28.

21. Pronobis, M., Evaluation of the influence of biomass co-combustion on boiler furnace slagging by means of fusibility correlations. Biomass and Bioenergy, 2005. 28(4): p. 375383.

22. Clarke, L.B. and Sloss, L.L., Trace elements - emissions from coal combustion and gasification. IEA Coal Research Report, 1992.

23. Williams, A., Jones, J.M., Ma, L. and Pourkashanian, M., Pollutants from the combustion of solid biomass fuels. Progress in Energy and Combustion Science, 2012. 38(2): p. 113137.

24. Glassman, I. and Yetter, R., Combustion. 4th ed. Academic Press, 2008.

25. R.M.Davidson, Chlorine in Coal Combustion and Co-firing. IEA Clean Coal Centre, 2005. 
26. Wu, H., Glarborg, P., Frandsen, F.J., Dam-Johansen, K. and Jensen, P.A., Dust-Firing of Straw and Additives: Ash Chemistry and Deposition Behavior. Energy \& Fuels, 2011. 25(7): p. 2862-2873.

27. Jenkins, B.M., Bakker, R.R. and Wei, J.B., On the properties of washed straw. Biomass and Bioenergy, 1996. 10(4): p. 177-200.

28. Miller, S.F. and Miller, B.G., The occurrence of inorganic elements in various biofuels and its effect on ash chemistry and behavior and use in combustion products. Fuel Processing Technology, 2007. 88(11-12): p. 1155-1164.

29. Miles, T.R., Alkali deposits found in biomass power plants, a preliminary investigation of their extent and nature volume 1l. 1996.

30. Saddawi, A., Jones, J.M., Williams, A. and Le Coeur, C., Commodity Fuels from Biomass through Pretreatment and Torrefaction: Effects of Mineral Content on Torrefied Fuel Characteristics and Quality. Energy \& Fuels, 2011. 26(11): p. 6466-6474.

31. Werkelin, J., Skrifvars, B.-J., Zevenhoven, M., Holmbom, B. and Hupa, M., Chemical forms of ash-forming elements in woody biomass fuels. Fuel, 2010. 89(2): p. 481-493.

32. Deng, L., Zhang, T. and Che, D., Effect of water washing on fuel properties, pyrolysis and combustion characteristics, and ash fusibility of biomass. Fuel Processing Technology, 2013. 106(0): p. 712-720.

33. Liaw, S.B. and Wu, H., Leaching Characteristics of Organic and Inorganic Matter from Biomass by Water: Differences between Batch and Semi-continuous Operations. Industrial \& Engineering Chemistry Research, 2013. 52(11): p. 4280-4289.

34. Khan, B.I., Jambeck, J., Solo-Gabriele, H.M., Townsend, T.G. and Cai, Y., Release of arsenic to the environment from CCA-treated wood. 2. Leaching and speciation during disposal. Environ Sci Technol, 2006. 40(3): p. 994-9.

35. Townsend, T., Dubey, B., Tolaymat, T. and Solo-Gabriele, H., Preservative leaching from weathered CCA-treated wood. Journal of Environmental Management, 2005. 75(2): p. 105-113.

36. Townsend, T., Tolaymat, T., Solo-Gabriele, H., Dubey, B., Stook, K. and Wadanambi, L., Leaching of CCA-treated wood: implications for waste disposal. Journal of Hazardous Materials, 2004. 114(1-3): p. 75-91.

37. Lundholm, K., Boström, D., Nordin, A. and Shchukarev, A., Fate of Cu, Cr, and As During Combustion of Impregnated Wood with and without Peat Additive. Environmental Science \& Technology, 2007. 41(18): p. 6534-6540.

38. Rogers, J.M., Stewart, M., Petrie, J.G. and Haynes, B.S., Deportment and management of metals produced during combustion of CCA-treated timbers. Journal of Hazardous Materials, 2007. 139(3): p. 500-505.

39. Solo-Gabriele, H.M., Townsend, T.G., Messick, B. and Calitu, V., Characteristics of chromated copper arsenate-treated wood ash. Journal of Hazardous Materials, 2002. 89(23): p. 213-232.

40. Janin, A., Coudert, L., Blais, J.F., Mercier, G., Cooper, P., Gastonguay, L. and Morris, P., Design and performance of a pilot-scale equipment for CCA-treated wood remediation. Separation and Purification Technology, 2012. 85: p. 90-95.

41. Arvelakis, S., Gehrmann, H., Beckmann, M. and Koukios, E.G., Preliminary results on the ash behavior of peach stones during fluidized bed gasification: Evaluation of fractionation and leaching as pre-treatments. Biomass and Bioenergy, 2005. 28(3): p. 331-338. 
42. Lam, P.Y., Lim, C.J., Sokhansanj, S., Lam, P.S., Stephen, J.D., Pribowo, A. and Mabee, W.E., Leaching Characteristics of Inorganic Constituents from Oil Palm Residues by Water. Industrial \& Engineering Chemistry Research, 2014. 53(29): p. 11822-11827.

43. Carrillo, M.A., Staggenborg, S.A. and Pineda, J.A., Washing sorghum biomass with water to improve its quality for combustion. Fuel, 2014. 116(0): p. 427-431.

44. Ho, Y.S., Harouna-Oumarou, H.A., Fauduet, H. and Porte, C., Kinetics and model building of leaching of water-soluble compounds of Tilia sapwood. Separation and Purification Technology, 2005. 45(3): p. 169-173.

45. Jones, J.M., Darvell, L.I., Bridgeman, T.G., Pourkashanian, M. and Williams, A., An investigation of the thermal and catalytic behaviour of potassium in biomass combustion. Proceedings of the Combustion Institute, 2007. 31 II: p. 1955-1963.

46. Davidsson, K.O., Korsgren, J.G., Pettersson, J.B.C. and Jäglid, U., The effects of fuel washing techniques on alkali release from biomass. Fuel, 2002. 81(2): p. 137-142.

47. EPRI Report, Online Available.

http://mydocs.epri.com/docs/publicmeetingmaterials/1104/73NXUF94JP6/E236228_09_E PRIs_Biomass_. 